\title{
Earth's Stratosphere and Microbial Life
}

\author{
Priya DasSarma ${ }^{1}$, André Antunes ${ }^{2}$, Marta Filipa Simões ${ }^{2}$ \\ and Shiladitya DasSarma ${ }^{1 *}$
}

${ }^{1}$ Institute of Marine and Environmental Technology, Department of Microbiology and Immunology, University of Maryland School of Medicine, Baltimore, Maryland, USA

${ }^{2}$ State Key Laboratory of Lunar and Planetary Sciences, Macau University of Science and Technology (MUST), Avenida Wai Long, Taipa, Macau SAR, China

shiladityadassarma@gmail.com

DOI: https://doi.org/10.21775/cimb.038.197

\begin{abstract}
The Earth's atmosphere is an extremely large and sparse environment which is quite challenging for the survival of microorganisms. We have long wondered about the limits to life in the atmosphere, starting with Leeuwenhoek's observation of "animalcules" collected from the air. In the past century, significant progress has been made to capture and identify biological material from varying elevations, from a few meters above ground level, to the clouds near mountaintops, and the jet streams, the ozone layer, and even higher up in the stratosphere. Collection and detection techniques have been developed and advanced in order to assess the potential diversity of life from very high altitudes. Studies of microbial life in the stratosphere with its multiple stressors (cold, dry, irradiated, with low pressure and limited nutrients), have recently garnered considerable attention. Here, we review studies of Earth's atmosphere, with emphasis on the stratosphere, addressing implications for astrobiology, the dispersal of microbes around our planet, planetary protection, and climate change.
\end{abstract}

\section{Introduction}

Why is it important to study and understand the limits to life at the highest elevations in the atmosphere? Elevation is a limit to life that has not yet been fully explored. It is relevant for space exploration, the search for life 
outside our planet, as well as more down-to-Earth concerns such as climate and disease.

In this review, we focus on conditions in the upper atmosphere, especially the stratosphere (Figure 1), and primarily on what is known about how microorganisms can survive there, under extreme conditions. The stratosphere is the highest elevation of the atmosphere where life has been found and hence its importance in studies of microbiology in our atmosphere. Astrobiology research has utilized Earth's stratosphere and its conditions as an analogue to conditions found on Mars, addressing whether extremophilic and other hardy microorganisms that survive in the stratosphere may tolerate conditions on the surface of Earth's sister planet. Here, we explore both the stressors encountered and the associated microbial responses. However, since studies of the stratosphere are relatively few, we also refer to a set of atmospheric analyses conducted in the troposphere or closer to Earth's surface for comparison and contrast. We present a summary of the studies which have contributed to our current level of understanding as well as the implications for astrobiology, climate, and health.

A relatively limited number of microbes have been collected from or exposed to the stratosphere, and most of them were either dormant or otherwise metabolically inactive, such as spores and lyophilized cells (Moeller and Horneck, 2004). In a sole instance, metabolically active microbes in growth media were launched into the stratosphere and returned to Earth (DasSarma and DasSarma, 2018). These cells retained viability, suggesting that ice entrapment may enhance microbial survival. Sampling and experimentation missions in the stratosphere are technically challenging and further work needs to be done to catalog and characterize cells that successfully survive. Technical issues of these studies, such as potential contamination during sample collection, can be a significant concern. Nevertheless, it is imperative to understand microbial survival strategies from the perspective of life in multiple extreme conditions like the stratosphere.

\section{From Aerobiology to Exobiology}

Aerobiology is the scientific field that studies the passive transport of biological particles through the atmosphere and its effect on living systems and the environment. In general, it has focused on particles of biological origin (bioaerosols), ranging from 0.2 to $2.5 \mu \mathrm{m}$ in diameter, which make up $25 \%$ of atmospheric particles (Griffin et al., 2018). With higher elevation and the complete disappearance of the atmosphere, aerobiology transitions to space biology or astrobiology (used by several authors as a synonym for exobiology). As early as 1960, Lederberg first used the term "exobiology" to describe the exploration of life in higher elevations, from the stratosphere into the realm of space, during his presentation at the $1^{\text {st }}$ 
International Space Science Symposium sponsored by the international Committee on Space Research (COSPAR) (Lederberg, 1960).

Research in aerobiology began with Earth-based questions, focusing on the spread of diseases. In 1546, Girolamo Fracastoro suggested that disease was transmitted not only by direct contact with a sick person, or contagion through contaminated objects, but also by transmission through the air at a distance or ad distans (Dubos, 1986). After the discovery of the microscope, Antoine van Leeuwenhoek determined, in 1702, that "animalcules" could be carried by the wind, together with dust floating in the air. John P. Ehrenberg examined air and dust specimens, collected by Charles Darwin on his trip on the H.M.S. Beagle in the 1830s, and found that it was composed of a multitude of "infusoria" (Darwin, 1846), a term commonly used at that time to describe microscopic life. In another study, Ehrenberg concluded the existence of an atmospheric "kingdom" of life, detected $6 \mathrm{~km}$ high in the Himalayas (Cunningham, 1873).

In one of the first experimental studies of microbial composition versus elevation, Louis Pasteur used swanneck flasks to demonstrate that the number of microbes found in the air diminished with increasing altitude and also varied by location, time and atmospheric conditions. He found that there were fewer microbes at higher altitudes, such as at the peak of Montan Verte at $2 \mathrm{~km}$ height (Pasteur, 1860). Soon after that, H.G. Dyar examined air in New York, in the 1890s, and reported the presence of microorganisms, predominantly Micrococcus, Bacillus and Sarcina, albeit at much more moderate elevations as these were collected closer to the surface (Dyar, 1894).

A number of studies starting in 1921 addressed the spread of fungal diseases of wheat and other agricultural grains in the United States (US). In 1934, a survey conducted dozens of flights over Boston and detected bacteria, molds, yeast and pollen at a height of 5-6 km (Proctor, 1934). Subsequently, the US Department of Agriculture commissioned further studies on the epidemiology of rusts and other plant diseases, leading F.C. Meier and Charles Lindbergh to collect bioaerosols from about $3 \mathrm{~km}$ elevation above sea level (ASL). For sample collection, they used an oiled microscope slide extended from the plane by a metal arm. This study collected samples from Maine to Copenhagen (via the Arctic) and tentatively identified microbes belonging to Macrosporium, Cladosporium, Leptosphaeria, Mycosphaerella, Trichothecium, Helicosporium, Uromyces, Camasosporium, and Venturia. They also found diminishing numbers as collections progressed over the sea ice cap of Greenland (Meier and Lindbergh, 1935).

Around the same time, a manned US high-altitude balloon, Explorer II, became the first air sampling mission to reach the stratosphere (up to 21 $\mathrm{km} \mathrm{ASL}$ ), and several viable microbes were isolated within the genera 
Bacillus, Macrosporium, Aspergillus, Penicillium and Rhizopus, using autoclaved collection tubes (Rogers and Meier, 1936). In 1965, G.A. Soffen flew balloons even higher, up to $40 \mathrm{~km} \mathrm{ASL}$, and used an ethylene oxidesterilized impactor for isolation, but only found Penicillium species (Soffen, 1965).

In the 1970s, A. A. Imshenetsky and colleagues collected samples of air from even higher elevations, from the stratosphere to the mesosphere (48-85 km ASL), using y-radiation sterilized meteorological rockets and investigated the characteristics of the bacterial and fungal strains isolated. They also studied the effects of the various atmospheric stressors, which continues to be one of the most remarkable investigations of microbial isolates from the highest elevations ever reported (Imshenetsky et al., 1976; Imshenetsky et al., 1977; Imshenetsky et al., 1978; Imshenetsky et al., 1979).

These early studies set the stage for more recent endeavors, including collection from the stratosphere by both planes and balloons (DeLeonRodriguez et al., 2013; Griffin, 2004; Smith et al., 2010). Balloons continue to be valuable for stratospheric studies as they can remain in place for sampling, exposure and experimentation, and may be flown to higher altitudes carrying larger payloads than most planes. In addition, balloons are advantageous because they can be maneuvered to many different locations and do not require expensive landing strips when returning samples to Earth (Smith et al., 2010; Smith and Sowa, 2017).

\section{The Atmosphere}

Many recent atmospheric studies have resulted in significant implications for health, including providing a better understanding of epidemiology, climate patterns and change, and planetary protection. However, the challenges continue to be considerable, with the atmosphere constituting the largest fraction of the biosphere. The mass of the Earth's atmosphere is $5.1 \times 10^{18} \mathrm{~kg}$ (or $\sim 1 / 1,200,000^{\text {th }}$ of the planet), with $50 \%$ of atmospheric mass located above $5.6 \mathrm{~km}, 10 \%$ above $16 \mathrm{~km}$, and $0.1 \%$ above $100 \mathrm{~km}$ (Lutgens and Tarbuck, 1995). The diversity and distribution of atmospheric life are considerably sparse when compared to terrestrial and aquatic environments. Answers to fundamental questions about the nature of life in the atmosphere and its survival are likely to lead to very significant results for both human health and the health of the planet.

\section{Evolution of Earth's atmosphere}

Earth's atmosphere has functioned for eons as a protective buffer for life on our planet. After the initial Hadean era, more than 3.4 billion years ago, before the evolution of life, the atmosphere primarily consisted of hydrogen and helium gases. As the atmosphere cooled, it became rich in nitrogen and carbon dioxide gases. During this very early period of the Earth's history, the sun was also dimmer by about $30 \%$ compared to the present 
day. Around 2.3 billion years ago, the Great Oxidation Event resulted in the atmosphere becoming oxygen-rich and evolving into its modern composition over time. Solar radiation catalyzed the conversion of molecular oxygen into ozone in the upper atmosphere, which resulted in heating and temperature inversion, providing the planet with an UVprotective layer in the stratosphere, critical for subsequent development and successful spread of life (Henderson and Salem, 2016; DasSarma and DasSarma, 2018; DasSarma and Schwieterman, 2018).

In the Anthropocene, many environmental factors contribute to further changes in the atmosphere. Jet travel, rocketry, military activities, and industrial and household pollution are all contributing to these changes and the natural barriers that prevent the transport and mixing between the layers of the atmosphere, e.g. troposphere and stratosphere, are being disrupted. Nevertheless, there are still some important questions that remain to be answered: a) Are anthropogenic activities responsible for the eutrophication of clouds and the atmosphere?, b) To what extent are anthropogenic activities contributing to climate change?, c) To what degree is the higher atmosphere, especially the stratosphere, subject to anthropogenic factors?, and d) Is it a habitat/place where life is expanding and serving as conduit for the dispersal of bioaerosols?

\section{Layers of the Atmosphere}

The atmosphere is divided into five main layers (from closest to furthest from the Earth's surface) (Figure 1), with this review focusing only on the lowest two (i.e. the ones where life seems to thrive).

\section{Troposphere}

The lowest level of the atmosphere, the troposphere, clearly contrasts with the stratosphere in terms of the necessary components for life maintenance: nutrients, in the form of dust particles and chemical compounds, air with all its components, water and water vapor. Like Earth's atmosphere in general, it is composed of $78 \%$ nitrogen, $21 \%$ oxygen and $1 \%$ of trace gases (argon, carbon dioxide, and most of the atmospheric water vapor). Temperature in this layer decreases with increasing height by $\sim 7^{\circ} \mathrm{C} / \mathrm{km}$, ranging from 15 to $-60^{\circ} \mathrm{C}$ (Vargin et al., 2015). The troposphere is where most weather events occur and is a characteristically turbulent and well-mixed layer. Jet streams, associated with frontal weather (where two different air masses meet), occur at or below the tropopause.

Most studies carried out thus far on life in the atmosphere have been within the troposphere. These studies provide the foundation for stratospheric analyses, addressing many of the challenges found at the higher altitudes. Tropospheric research has shown not only the presence of microbes, but also their metabolic activity (e.g. Klein et al., 2016). Culturing and metagenomic studies have identified a range of microbes that may be residents or have been transported into the troposphere where they may 


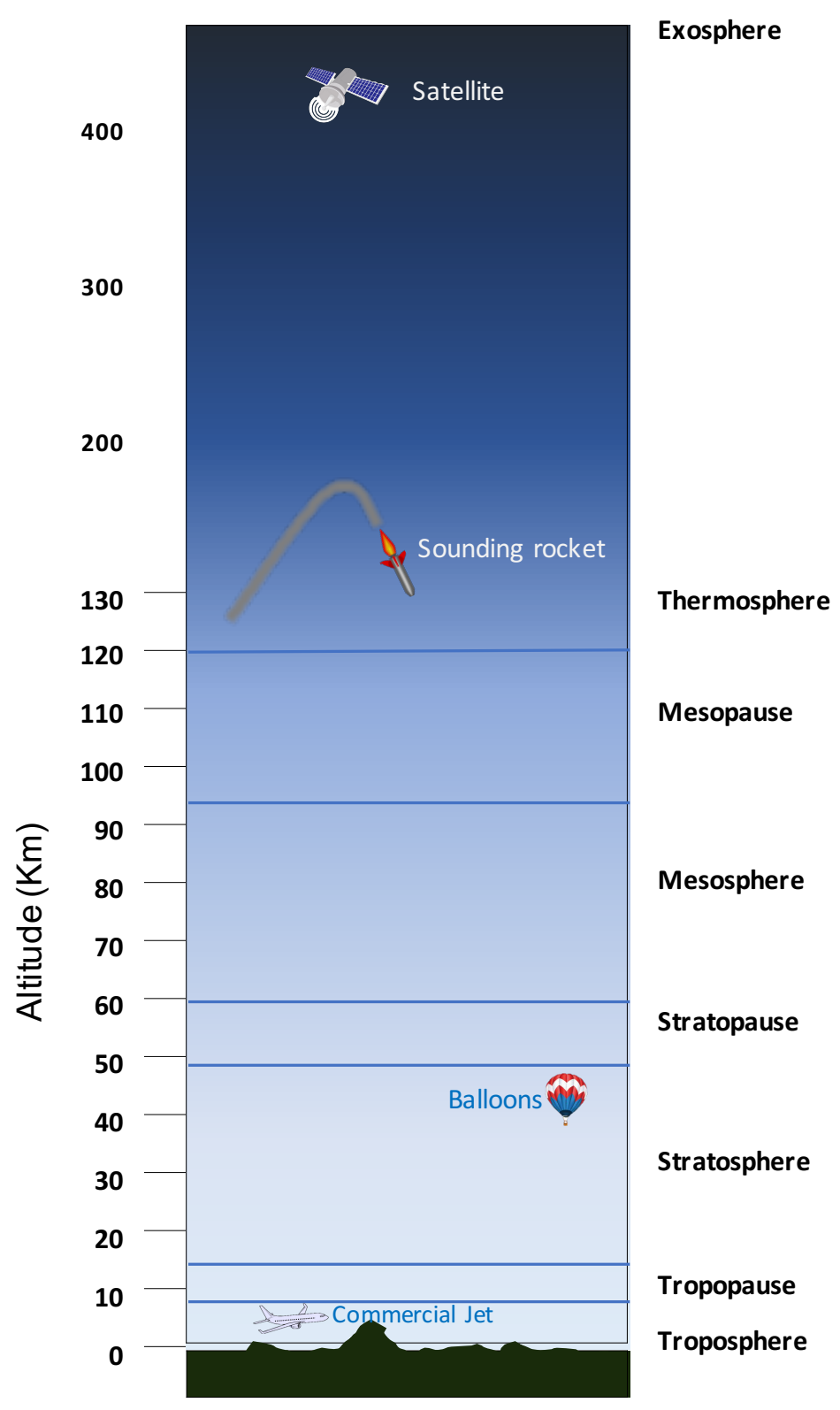

Figure 1. Overview of the different layers of Earth's atmosphere and their characteristics. 


\section{Exosphere}

The top layer is the exosphere, located above the thermosphere and also considered to be part of space. It extends to at least $10,000 \mathrm{~km}$, where it merges with the Solar wind (a constant stream of plasma and charged particles released from the corona, the Sun's outer layer). The exosphere is where most Earth-orbiting satellites are located.

\section{Thermosphere}

The thermosphere is located at heights above the mesopause with temperatures up to $1700 \mathrm{oC}$. It has a very low density of particles, is cloudless, and lacks water vapor altogether. This is where the International Space Station is located (at 350-420 km). The thermosphere ends with the thermopause, also called the exobase, $\sim 600-1000$ $\mathrm{km}$, depending on solar activity.

\section{Mesosphere}

The mesosphere occupies heights from the top of the stratopause to $95-120 \mathrm{~km}$, where the temperature decreases with height, at which point the mesopause, known as the coldest place on Earth with average temperature of $-850 \mathrm{C}$ is located. This is the layer where meteors burn up, sounding rockets and rocket-powered aircraft travel, and where the highest clouds, noctilucent, or night-glowing, made of ice crystals, and seen only during astronomical twilight exist.

\section{Stratosphere}

The stratosphere occupies heights from the top of the troposphere up to $50-60 \mathrm{~km}$. Here, the temperature increases with height. This is the highest region where jet planes fly ( 10-13 km). The stratosphere ends at the stratopause (Figure 1).

\section{Troposphere}

The troposphere occupies 15-18 km heights in the tropics and 10-12 km at the Polar Regions, with the temperature decreasing with increasing height. At the top of the troposphere, the tropopause separates the troposphere from the stratosphere.

be dormant or dead. The troposphere is considered a microbial ecological niche and ecosystem that requires study with efforts similar to that used in terrestrial and aquatic environments.

\section{Clouds}

About $15 \%$ of the first $6 \mathrm{~km}$ of the atmosphere consists of clouds, and several studies have focused on the importance of nucleation in both cloud and fog formation (Delort et al., 2010). Both homogeneous and heterogeneous particles are found near clouds and close to the tropopause. Ultrafine particles (3-15 nm in diameter) can serve as cloud condensation nuclei, which can grow to $100 \mathrm{~nm}$ within a few days (Kulmala et al., 2004).

Culturing, phylogenetics, and metagenomics have been used to extensively analyze cloud matter (Xu et al., 2017). Culture-based studies have identified bacteria (including $\alpha-, \beta$ - and $\gamma$-Proteobacteria, Bacteroidetes, Firmicutes and Actinobacteria), and fungi (Basidiomycetes and Ascomycetes) $1.5 \mathrm{~km}$ above the volcanic dome of Puy de Dôme. They 
found that less than $1 \%$ of bacteria and about $10 \%$ of fungi (e.g. Dioszegia and Udeniomyces) were reported to be culturable (Vaïtilingom et al., 2012). Another study reported that $\sim 17 \%$ of known fungal species can be grown in culture (Amato et al., 2017).

Microorganisms are also able to act as cloud condensation nuclei and their presence is conditioned by several factors, including local presence of carbon sources and in situ $\mathrm{pH}$. Data from the troposphere includes carboxylic acids and alcohols at concentrations of up to $1 \mathrm{mg} / \mathrm{L}$, and a variety of hydrocarbons at concentrations $\leq 4 \mathrm{ng} / \mathrm{L}$ and $\mathrm{pH}$ ranging from 3-7, with acidity resulting from dissolved gases and compounds from aerosols in cloud water. Sulfate and nitrate nutrients in cloud water and rainwater can be relatively high and even reach levels typically found in oligotrophic lakes. The microorganisms previously detected in clouds include: Micrococcus agilis, Mycoplana bullata, and Brevundimonas diminuta, as well as plant pathogens such as Erwinia carotovora (Pérez-Díaz et al., 2017). Furthermore, species of the genus Pseudomonas detected in clouds have been shown to have nucleation properties, as they produce biosurfactants that facilitate the condensation of water on the surface of their cells. As a result, they are able to induce cloud formation, enhancing precipitation in the form of rain or snow (Amato, 2012).

Studies quantifying ATP concentrations and using differential staining have found that as much as $\sim 1$ million tons/year of organic carbon is metabolized by bacteria in the clouds (Vaïtilingom et al., 2013). Among these are the metabolically active oligotrophic, pigmented Sphingomonas spp. which have a high resistance to UV, cold and salinity, and can tolerate relatively high concentrations of oxidants. In addition, Pseudomonas spp. were found to use a variety of carbon compounds, though they were found to be less resistant to UV and oxidants. These microbes may use the atmosphere and clouds for both residence as well as for transport, until rain or snow brings them back to the Earth's surface (Delort et al., 2010; Xu et al., 2017). In another study, metagenomic analysis of cloud water samples from Mt. Tai ( 1.5 km elevation), in China, also identified Proteobacteria, Bacteroidetes, Firmicutes, and Actinobacteria as predominant bacterial groups. Here, researchers also concluded that ozone and sulfur dioxide $\left(\mathrm{SO}_{2}\right)$ contributed to the variability of populations in these environments $(\mathrm{Xu}$ et al., 2017).

\section{Dust}

While microbes may be expected in the humid environment of clouds, studies into the transport of microbes by dust have led to some unexpected discoveries. Sources of aerosolized particulate matter can originate from e.g. vehicular pollution, construction, and industry as well as wind erosion (Griffin et al., 2018). Erosion sources include the $\sim 10$ million acres of farmland annually that are lost due to poor agricultural techniques and weather, dust storms from deserts, overgrazing, and deforestation. Most 
wind-borne bacteria may be transported for relatively short distances, $<1$ $\mathrm{km}$ from their source, although some seem to be transported for extremely long distances, reportedly over 5,000 km (Kellogg and Griffin, 2006). Each year, more than $90 \times 10^{9} \mathrm{~kg}$ of dust are lifted from the Sahara Desert into the atmosphere, making up the Saharan air layer at about $6 \mathrm{~km} \mathrm{ASL}$, and crossing the Atlantic in 5-7 days (Di Liberto, 2018; Griffin et al., 2003). As an additional example, each year, $\sim 8$ million metric tons of lake-bed sediment from the dry Lake Owens bed in California are transported into the atmosphere and make up the primary source of atmospheric dust in the continental USA (Griffin et al., 2002).

It may be possible for microorganisms to take a ride in the tropospheric and stratospheric wind currents (Creamean et al., 2013; Barberán et al., 2015). Dust-associated bacterial and fungal spores have been reported to be transported across the Atlantic, from Africa to the Caribbean (Kellogg and Griffin, 2006). It has been calculated that the Sahara and Sahel regions of North Africa account for approximately $50-75 \%$ of the annual total atmospheric dust load (Griffin et al., 2018). In one study, halophilic endospores associated with Asian dust, or KOSA (the Japanese term for yellow sand), particles and other bioaerosols were mentioned as being transported across Asia from the Gobi Desert to Japan by dust storms (Echigo et al., 2005). Furthermore, it was found that these KOSA particles can act as enhancers of microbial growth (Maki et al., 2011).

Bacillus and Microbacterium were reported as the predominant bacteria isolated in several studies from African dust storms (Kellogg and Griffin, 2006). Metagenomic analyses of Caribbean and African dust storm events found that the microbes identified were the same. For example, the $18 \mathrm{~S}$ sequences of Cladosporium isolates from the Caribbean samples were 99$100 \%$ identical to an isolate from African dust, indicating that these microorganisms may have been transported through the atmosphere (Kellogg and Griffin, 2006).

Results of such studies vary depending on numerous factors, including sampling methods, analysis and likely variability in the atmosphere at any given location and weather condition. For example, in two studies from Taiwan, dust from various time points was collected, including storms that transport dust from China and Mongolia to Taiwan, and spores were morphologically identified using microscopy-based analysis. In one study, ascospores and spores from Cladosporium, Penicillium, and Aspergillus, were found to be dominant in dust; though, only Cladosporium spore levels increased during dust storms. In addition, Ganoderma, Arthrinium, Papularia, Cercospora, Periconia, Alternaria, and Botrytis spores were also identified (Ho et al., 2005). In another study, the dominant spores of Penicillium, Aspergillus, Nigrospora, Arthrinium, Curvularia, Stemphylium, Cercospora, and Pithomyces, were found $15 \mathrm{~m}$ above ground level in calm conditions; and, only Penicillium, Aspergillus, Nigrospora, and some 


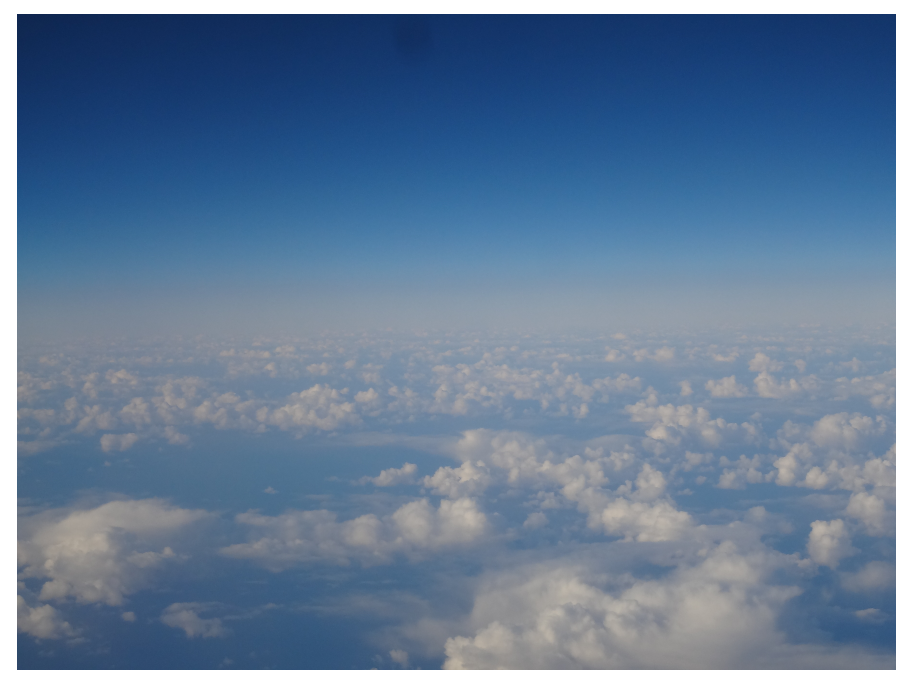

Figure 2. View from the window of a commercial airliner at $12 \mathrm{~km}$ altitude. Below are tropospheric clouds, above, the clear zone of the stratosphere.

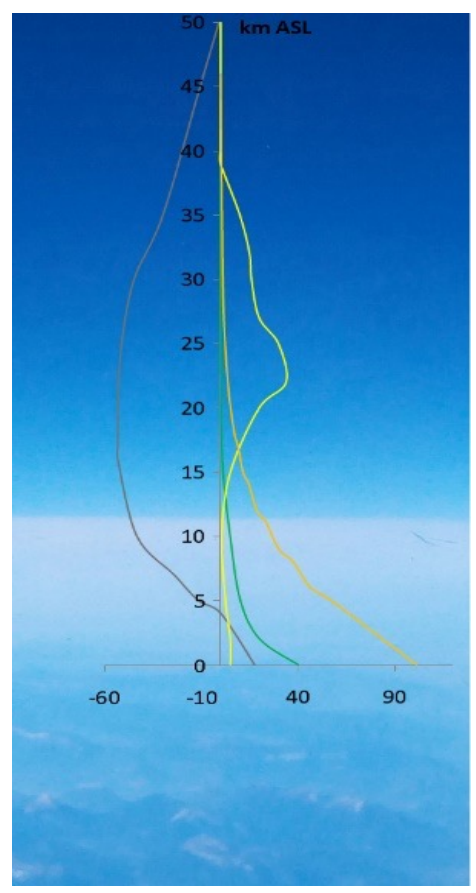

Figure 3. Selected characteristics of the troposphere and stratosphere. Average temperature $\left({ }^{\circ} \mathrm{C}\right)$, gray; average water vapor $\left(\mathrm{g} / \mathrm{m}^{3}\right)$, green; barometric pressure $(\mathrm{kPa})$, orange; and ozone $(\mathrm{mPa})$, yellow on $\mathrm{x}$-axis, plotted against km above sea level (ASL) on y-axis. 
unidentified spores were found to have increased concentrations during dust storm events (Wu et al., 2004).

The numbers of culturable airborne microorganisms were found to increase 2 to 3-fold during African dust-events. Direct microbial counts of air samples using epifluorescent microscopy, determined that bacteria- and virus-like particle counts were $\sim 10$-fold greater during these events than during clear conditions. Also, autofluorescence was exhibited by bacterialike particles during an African dust-event, further supporting the presence of microorganisms (Griffin et al., 2001). Also, epifluorescent microscopy of nucleic acid stained filters of material from dust events showed that the bacterial and viral counts were the same, in contrast to results from soil and marine environments, where the viral counts were an order of magnitude higher. This suggests that viral particles are more susceptible to the high UV radiation and dry air associated with long-distance transport in dust events (Kellogg and Griffin, 2006).

At the top of the troposphere, the tropopause acts as a barrier to particulate matter, with peak heights over the equator and minimum heights over Polar Regions. Temperature inversion occurs in the tropopause, from decreasing with increasing height in the troposphere, to increasing with increasing height in the stratosphere (negative lapse rate) (Mohanakumar, 2008; Gettelman et al., 2011). The temperature in the tropopause is isothermal, and effectively stops the transfer of most aerosols from the troposphere into the stratosphere. It is also the region where the atmosphere becomes exceedingly dry (Gettelman et al., 2011).

\section{Stratosphere}

There is some variability in the height of different layers in the atmosphere, depending on factors such as e.g. latitude, season, atmospheric conditions and solar activity. The stratosphere (Figure 2), located above the troposphere and tropopause, can start as low as $\sim 7 \mathrm{~km}$ near the poles and as high as $20 \mathrm{~km}$ at the equator and extends up to approximately $50-60 \mathrm{~km}$ ASL. Conditions here are among the most extreme on Earth and comparable to conditions found on the surface of Mars, making it valuable as a Mars analog (Figure 3). This Martian analogue status is supported by data from several studies. Indeed, the stratosphere has low nutrient availability, reduced atmospheric pressure (between 0.1 to $10 \mathrm{kPa}$ ), low temperatures (around $-50{ }^{\circ} \mathrm{C}$ ), presence of toxic chemical species, and intense solar radiation and is extremely dry (relative humidity $23 \%$ ) (Smith et al., 2011; Smith et al., 2013).

There is some drastic variation in conditions within the stratosphere. Near the top of this layer, the pressure is extremely hypobaric $(\sim 0.1 \%$ of that at sea level). Furthermore, its high concentrations of ozone and ozone layer restrict weather-producing turbulence and mixing. Temperature increases from $-70^{\circ} \mathrm{C}$ at the tropopause, to $0^{\circ} \mathrm{C}$ at the top of the stratosphere due to 
Table 1. Overview of microbes isolated from and/or tested in the stratosphere*.

\begin{tabular}{|c|c|c|c|c|}
\hline Isolate name & Domain & Height (km ASL) & $\begin{array}{l}\text { GC- } \\
\text { composition* }^{*}\end{array}$ & $\begin{array}{l}\text { Spore } \\
\text { former? }\end{array}$ \\
\hline Actinobacteria & Bacteria & $18-29^{\prime}$ & Variable & Some \\
\hline Actinomyces sp. & Bacteria & $19^{\top}$ & High & $\begin{array}{l}\text { May form } \\
\text { endospores }\end{array}$ \\
\hline Aspergillus fumigatus, Aspergillus niger & Eukarya & $11-21^{\prime}, 48-77^{\prime}, 19-22^{\top}$ & $\sim 50 \%$ & Yes \\
\hline $\begin{array}{l}\text { Bacillus endophyticus, } \\
\text { Bacillus luciferensis, } \\
\text { Bacillus pumilus SAFR-032, Bacillus } \\
\text { simplex, } \\
\text { Bacillus (Lysinibacillus) sphaericus, } \\
\text { Bacillus subtilis }\end{array}$ & Bacteria & $20-77^{\top}, 20-30^{\top}$ & Low & $\begin{array}{l}\text { Endospore } \\
\text { forming }\end{array}$ \\
\hline Brachysporium sp. & Eukarya & $22^{\top}$ & ND & $\begin{array}{l}\text { Spore- } \\
\text { forming }\end{array}$ \\
\hline Brevibacterium luteolum & Bacteria & $20^{1}$ & High & No \\
\hline Circinella muscae & Eukarya & $48-77^{1}$ & ND & $\begin{array}{l}\text { Spore- } \\
\text { forming }\end{array}$ \\
\hline Cladosporium sp. & Eukarya & $22^{\top}$ & $\sim 50 \%$ & $\begin{array}{l}\text { Spore- } \\
\text { forming }\end{array}$ \\
\hline $\begin{array}{l}\text { Deinococcus aetherius, Deinococcus aerius } \\
\text { TR0125 }\end{array}$ & Bacteria & $10-12^{1, T}$ & High & No \\
\hline Diplodia sp. & Eukarya & $22^{\top}$ & High & ND \\
\hline Engyodontium albus & Eukarya & $41^{1}$ & ND & $\begin{array}{l}\text { Spore- } \\
\text { forming }\end{array}$ \\
\hline Escherichia coli & Bacteria & $40^{\top}$ & $\sim 50 \%$ & No \\
\hline Eurotiomycetes sp. & Eukarya & $20^{1}$ & ND & ND \\
\hline Exophiala sp. 15LV1 & Eukarya & $25-30^{\top}$ & ND & ND \\
\hline Fusarium sp. & Eukarya & $19^{\top}$ & $\sim 50 \%$ & ND \\
\hline Halobacterium species NRC-1 & Archaea & $36^{\top}$ & High & No \\
\hline Halorubrum lacusprofundi & Archaea & $36^{\top}$ & High & No \\
\hline Helminthosporium sativum & Eukarya & $22^{\top}$ & ND & ND \\
\hline Hysterium sp. & Eukarya & $22^{\top}$ & $\sim 50 \%$ & ND \\
\hline Macrosporium sp. & Eukarya & $11-21^{\prime}, 19^{\top}$ & ND & ND \\
\hline Micrococcus albus & Bacteria & $48-77^{\mid}$ & High & No \\
\hline Monilia sitophila & Eukarya & $19^{\top}$ & ND & ND \\
\hline Mycobacterium luteum & Bacteria & $48-77^{1}$ & ND & $\begin{array}{l}\text { May form } \\
\text { spores }\end{array}$ \\
\hline $\begin{array}{l}\text { Naganishia (Cryptococcus) friedmannii } \\
\text { 16LV2 }\end{array}$ & Eukarya & $25-30^{\top}$ & ND & ND \\
\hline Paenibacillus sp. & Bacteria & $12-35$ & $\sim 50 \%$ & $\begin{array}{l}\text { Spore- } \\
\text { forming }\end{array}$ \\
\hline Papulaspora anomala & Eukarya & $48-77^{1}$ & ND & ND \\
\hline $\begin{array}{l}\text { Penicillium cyclopium, Penicillium } \\
\text { chrysogenum (formerly notatum), } \\
\text { Penicillium sp. }\end{array}$ & Eukarya & $11-77^{\prime}, 19^{\top}$ & $\sim 50 \%$ & \\
\hline Pestalozzia sp. & Eukarya & $19^{\top}$ & ND & ND \\
\hline Proteobacteria & Bacteria & $18-291$ & ND & ND \\
\hline Proteus mirabilis & Bacteria & $40^{\top}$ & Low & No \\
\hline Pseudomonas aeruginosa & Bacteria & $40^{\top}$ & High & No \\
\hline Puccinia graminis & Eukarya & $19^{\top}$ & Low & ND \\
\hline Rhizopus sp. & Eukarya & $11-21^{\perp}, 19^{\top}, 22^{\top}$ & Low & ND \\
\hline Salmonella enterica Serovar Typhimurium & Bacteria & $40^{\top}$ & $\sim 50 \%$ & No \\
\hline $\begin{array}{l}\text { Staphylococcus pasteuri, Staphylococcus } \\
\text { aureus MRSA, } \\
\text { Staphylococcus aureus }\end{array}$ & Bacteria & $41^{\top}, 40^{\top}$ & Low & No \\
\hline
\end{tabular}


ozone absorbing UV rays and consequently releasing heat (Smith et al., 2011).

The stratosphere is almost devoid of clouds, with the exception of the tall cumulonimbus clouds, also called thunderheads, observed during storms, which can penetrate from the troposphere through the tropopause into the stratosphere. In the coldest polar regions, nacreous clouds may also be observed (Henderson and Salem, 2016). Cloud formation can sometimes occur at the tip of the boundary layer under extremely polluted conditions or during the winter in polar regions at temperatures below $-78^{\circ} \mathrm{C}$ and form polar stratospheric clouds at 15-25 km (Ursem, 2016).

Chemical components of the stratosphere include: water vapor, methanol, nitrogen oxides and bromide, as well as a background aerosol layer consisting mainly of binary sulfuric acid-water aerosol droplets (Vargin et al., 2015; Smith and Sowa, 2017). Molecular hydrogen $\left(\mathrm{H}_{2}\right)$ is an atmospheric trace gas and acts as a source of water vapor in the stratosphere (Meredith et al., 2017). Most of the known aerosol nanoparticles in the stratosphere are found at 17-50 km ASL, and result from large volcanic eruptions and major meteorite impacts. They are known to have global effects for months or years and have been directly related to the Earth's climate alterations (Ursem, 2016).

For nearly 100 years, humans have been able to enter the stratosphere. In 2014, the Air Transport Action Group estimated the number of scheduled flights to be close to 100,000 per day. Adding to this number, other human sources of stratospheric breaches include orbital launches (which in 2017 consisted of 29 launches from the United States, 20 from Russia and 18 from China; Leary, 2018), and launches of weapons and other military material. All of these can contribute to the dispersal of hitchhiking microorganisms and organic elements into the upper troposphere, lower stratosphere, or higher, and is termed "artificial panspermia" (Lederberg, 1960).

In addition to potential microbial "hitchhikers" on these vehicles, there may also be microbial matter that made its way there via natural means. Natural sources include volcanic activity, storms, wind, fires, and clouds. Whether any of these microbes are metabolically active or even reproduce in the stratosphere is yet to be determined. To date, bacterial and fungal spores dominate the isolates found (Table 1). In addition, experiments that involve launches of microbes into the stratosphere have shown that a trip into the stratosphere is indeed non-fatal to metabolically inactive spores, lyophilized cultures of bacteria and fungi, and active cultures of halophilic archaea (Table 1) (DasSarma and DasSarma, 2018). 


\section{Extreme conditions in the Stratosphere}

There are a multitude of extreme conditions that make it difficult for most microbes to survive stratospheric conditions, including: irradiation, desiccation, freeze-thaw cycles, low pressure, and lack of water and nutrients. Some of these stressors can also be observed on the Earth's surface, but there is a complex combination of factors in the stratosphere that more closely mimics conditions on Mars than alternative analogue surface sites. This makes the study of the stratosphere of great interest to astrobiologists, who use this natural environment as a laboratory to study both a) the effects of Martian-like conditions (as proxy), e.g.: by testing the viability of organisms, and b) native microbial communities and inhabitants found in these environments. Research into microbial viability in simulations has shown that sun-illuminated bioaerosols are quickly inactivated in the laboratory through application of these stressors (Griffin et al., 2018).

Among the deadliest stressors in the stratosphere are the cosmic rays that constantly bombard our planet. Most of these are either deflected by the Earth's magnetic field or interact with air molecules. Cosmic rays include galactic cosmic rays (from outside the solar system), anomalous cosmic rays (from interstellar space at the edge of the heliopause), solar energetic particles from solar flares and other energetic solar events, and other types of cosmic rays, which include X-rays, $\mathrm{Y}$-rays, and the short wave ultra-violet (UV) portion of the electromagnetic spectrum (Christian, 2012). Cosmic rays are primary sources of ionizing radiation (IR) and carry enough energy to liberate electrons from atoms or molecules (UNSCEAR, 2008).

Damage from IR includes radiolysis of water that generates reactive oxygen species [ROS; e.g.: hydroxyl radicals $\left(\mathrm{HO}^{*}\right)$, superoxide $\left(\mathrm{O}_{2}{ }^{-}\right)$and hydrogen peroxide $\left(\mathrm{H}_{2} \mathrm{O}_{2}\right)$ ], which cause damage to nucleic acids, generating oxidized DNA bases and sugar moieties, abasic (apurinic or/and apyrimidinic) sites, and single-stranded breaks (SSBs) (Hutchinson, 1985; Imlay, 2006). With increasing doses of IR, the linear density of DNA base damage and SSBs increases on both strands and gives rise to double stranded breaks (DSBs). ROS damages proteins by introducing carbonyl residues, amino acid radical chain reactions, cross-linking, and ultimately results in protein inactivation and denaturation (Stadtman and Levine, 2003). $\mathrm{O}_{2}^{-}$does not easily cross membranes, and is not metabolized by the cell or react with DNA or most proteins; but it damages and inactivates enzymes with exposed $2 \mathrm{Fe}-2 \mathrm{~S}$ or $4 \mathrm{Fe}-4 \mathrm{~S}$ clusters causing release of $\mathrm{Fe}^{2+}$, which in turn reacts with $\mathrm{H}_{2} \mathrm{O}_{2}$ and catalyzes Fenton reactions (oxidation of organic substrates) (Imlay, 2006). IR can also cause 40 times more SSBs than DSBs when macromolecules absorb X-ray and $\mathrm{Y}$-ray photons, (von Sonntag, 1987; Daly et al., 1994).

Of all the stressors present in the stratosphere, short-wave UV radiation causes the greatest damage to cells. It causes an increase in ROS 
production, resulting in damage of biomolecules such as proteins, lipids, DNA and RNA. Stratospheric ozone reduces penetration of wavelengths $<320 \mathrm{~nm}$ and completely excludes those $<290 \mathrm{~nm}$. Thus, UV-A (315-400 $\mathrm{nm}$ ) which constitutes $95 \%$ of total energy of UV spectrum that reaches the Earth's surface does not damage organic material. The remaining $5 \%$ is UV-B (280-315 nm), which has the greatest biological impact on Earth. Some studies have predicted that aerosols are crucial factors involved in blocking UV-B radiation (Bais et al., 2018). UV-C $(100-280 \mathrm{~nm})$ is completely blocked by Earth's ozone layer in the stratosphere. However, above the ozone layer in the stratosphere, any bioaerosols present would experience high fluxes of UV-C radiation.

The destructive power of UV radiation was first determined to be an order of magnitude higher in air than in liquids (Wells and Fair, 1935). Whisler found that, effectiveness of UV to kill was determined not only by the source of radiation, but also by the type of organisms irradiated, with some air-borne microorganisms like Micrococcus luteus, Staphylococcus aureus, and Bacillus subtilis found to be considerably more tolerant of UV than Escherichia coli. M. luteus was found to be 100 times more resistant than E. coli, potentially due to clustering of their cells and shielding effects. $S$. aureus and sporulating cultures of $B$. subtilis were 3 and 8 times more resistant than $E$. coli, respectively. This lethal effect of UV radiation was also remarkably dependent on the relative humidity of the air, with cells being an order of magnitude more sensitive in dry air when compared to humid air (Whisler, 1940).

As conditions in the stratosphere also include low temperatures, low pressures and desiccating conditions, microorganisms in this environment would need to have cold- and freeze-adaptations, be able to tolerate hypobaric conditions and be xerotolerant (Rothchild and Mancinelli, 2001; Fletcher et al., 2014). Due to the sparseness of material in the stratosphere, it would be difficult for any living cells to find the building blocks of life needed to metabolize and reproduce, though attachment to particulate matter and the potential for a buildup of such materials, from natural or anthropogenic sources, may provide some resources.

\section{Entry and return of material}

Some of the natural uplift mechanisms, capable of driving vertical transport of aerosols into the atmosphere, include convective overshooting and strong up-drafting forces generated by processes associated with thunderstorms, typhoons, monsoons, hurricanes, and cyclones. Largescale storms, especially hurricanes and cyclones, may reach into the lower stratosphere as they cross oceans. Blue jets, which are optical flashes above thunderclouds, propagate upwards from thunderclouds to $\sim 70 \mathrm{~km}$. Stratosphere-troposphere exchange occurs by deep convection in the tropics, tropopause folding, convective overshooting, as well as by meteors (Wilson et al., 1978; Pasko et al., 2002; Smith and Sowa, 2017; Berera, 
2017, Griffin et al., 2018). Volcanic eruptions can send ash and other material 2-45 km and possibly higher $(55 \mathrm{~km})$ into the atmosphere, with a dust load of $4-25 \times 10^{6}$ tons in a single eruption (Griffin et al., 2018). Particle loads, from large eruptions, are known to force climate change through the resulting changes in planetary solar irradiance and contribute to bioaerosols being swept into the stratosphere (Rohatschek, 1984).

Aerosol particles' lifetime (such as those from volcanic eruptions) in the stratosphere, has been calculated to be 1 to 2 years and results in reduction of solar radiation to the Earth's surface and, in turn, reduction of surface temperature. This is unlike the troposphere, where particles are rapidly removed via precipitation (Vargin et al., 2015). Other calculations indicate that bacteria remain aloft for 2-10 days, and can travel over thousands of kilometers, while viruses are believed to be associated with particles in the nano- to micrometer range, with a predicted 2-188 days residency time (Cuthbertson and Pearce, 2017; Amato et al., 2017). Eventually, in months to years, depending on the aerosol size, stratospheric aerosols return to the surface by Brewer Dobson circulation which is believed to move air masses towards the poles (Smith and Sowa, 2017).

Micron scale particles can be elevated to altitudes of $80 \mathrm{~km}$, due to irradiation of particles by sunlight through gravitophotophoretic effects and electrostatic levitation. In photophoresis, small particles, suspended in liquid or gas, start to migrate when illuminated by a sufficiently intense beam of light because of non-uniform temperature distribution. This levitation occurs only with negative photophoresis, and it has been predicted that pointing towards the sun would create a lifting component exceeding the gravitational force. Furthermore, it was also concluded that some particles in the stratosphere may rise against the force of gravity (Orr Jr and Keng, 1964; Rohatschek, 1996). Experimental evidence indicated that gravitophotophoresis in sunlight causes the ascent or the suspension in the middle atmosphere of carbonaceous, mineral, and metallic particles, mainly in the 1-10 $\mu \mathrm{m}$ size range, which otherwise would fall with considerable velocity (Rohatschek, 1984). Particles in the 1-100 $\mu \mathrm{m}$ size range were shown to levitate due to photophoretic forces in a laboratory simulation of solar and middle atmospheric air densities (Rohatschek, 1984). The studies of gravitophotophoresis suggested it may be the reason why microorganisms are found in the stratosphere and mesosphere (Imshenetsky et al., 1977). They also indicated that radiation absorbed by pigments produces photophoretic forces sufficient to overcome gravity (Rohatschek, 1984).

\section{Bioaerosols}

Materials of organic origin in the atmosphere are called bioaerosols, and can include microbes, spores and pollen. Some of this material is freefloating, while other can be found attached, trapped in, or on larger 
particles or aggregates (Smith et al., 2012; Smith et al., 2013). Primary biological aerosols represent $5-10 \%$ of the total number of atmospheric particles $>0.2 \mu \mathrm{m}$ in diameter (Amato et al., 2017). It has been predicted that $40-1800 \mathrm{Gg}$ of organic matter is aerosolized annually (Cuthbertson and Pearce, 2017). Bioaerosols may consist of raindrop-bubbles from soil which has been calculated to aerosolize $\sim 0.01 \%$ of soil surface bacteria (Joung et al., 2017). In this phenomenon, raindrops impacting the soil, form tiny bubbles and rupture at the raindrop/air interface, and cause emission of tiny water jets that are subsequently broken into aerosols containing soilassociated bacteria that are released into the air column (Joung et al., 2017; Jang et al., 2018). Microbes and viruses can also be transferred from the ocean surface to the marine aerosol (Rastelli et al., 2017). Some bioaerosol microbes in the troposphere are believed to be metabolically active and capable of reproduction, with a calculated doubling time of 3.6-19.5 days (Cuthbertson and Pearce, 2017). The metabolic processes identified include nitrogen processing, sulfur oxidation and reduction, and photosynthesis (Cuthbertson and Pearce, 2017).

A survey of virus-like particles in the Sierra Nevada Mountains, Spain, above the atmospheric boundary layer $(1.7 \pm 0.5 \mathrm{~km} \mathrm{ASL})$, determined that the flux of viruses ranges from 0.26 to $>7 \times 10^{9} / \mathrm{m}^{2}$ per day. These deposition rates were considerably greater than the rates for bacteria, which ranged from 0.3 to $>8 \times 10^{7} / \mathrm{m}^{2}$ per day. The highest relative deposition rates for viruses were associated with atmospheric transport from marine rather than terrestrial sources. Virus deposition rates were positively correlated with organic aerosols $<0.7 \mu \mathrm{m}$, whereas, bacteria were primarily associated with organic aerosols $>0.7 \mu \mathrm{m}$, implying that viruses could have longer residence times in the atmosphere and, consequently, may be dispersed further (Reche et al., 2018). A similar survey of stratospheric material would be useful to expand our understanding of this phenomenon.

Studies of aerosolized material in the atmosphere have been undertaken in recent years using metagenomic techniques. In a study of aerosol material before and after heavy rains in Korea, researchers used pyrosequencing to identify Actinobacteria, Firmicutes, Proteobacteria, and Bacteroidetes, and lesser quantities of Planctomycetes, Chloroflexi, Gemmatimonadetes, and Cyanobacteria in post-rain samples (Jang et al., 2018). Surprisingly, no archaeal sequences were reported; and, levels of the marine bacterial sequences ( $\alpha$-Proteobacteria, Actinobacteria, and Firmicutes) decreased after rainfalls. Sequences corresponding to the non-spore forming Actinobacteria and the phytopathogens Clavibacter michiganensis, Staphylococcus saprophyticus, and the human pathogen, Propionibacterium acnes, were often observed in post-rain air samples, whereas the Firmicutes decreased in abundance. The Firmicutes were more abundant in coarse particles than in fine particles and the study considered that precipitation may selectively remove particle-associated bacterial 
groups, causing changes in airborne bacterial community composition after rainfall, despite increases in overall bioaerosol concentration.

\section{Collection and analysis of material for microbiological studies}

Over $10^{21}$ cells/year are estimated to be lofted into the atmosphere, with only a small fraction $(<0.1 \%)$ believed to survive (Aguilera et al., 2018). How many of these actually exist in the stratosphere is still to be determined. Thus far, only a limited number of studies have been performed to address this question, and they include direct isolation from the stratosphere and simulations in the laboratory (DasSarma and DasSarma, 2018).

Analysis of collected material is conducted in two main ways: a) culturing and characterization, and b) DNA extraction and identification (Cuthbertson and Pearce, 2017; Griffin et al., 2018). Culturing results are dependent on both the collection method and media used, while DNA extraction will vary based on the methods used, which may selectively be easier for some microbes and more difficult for others. Polymerase chain reaction (PCR) and sequencing methods may also introduce biases based for example on the primer sequences used. Given the limited number of studies thus far, no preferred methods for stratospheric collection studies have arisen.

One of the earliest methods used, the plate-fall/drop-plate technique, involves leaving agar plates open to allow material to drop into it. This method is hard to implement when material is scarce, or gravity is less effective. It is probably not feasible for the stratosphere, since centrifugation would be a necessary step difficult to perform at this height, but has been used widely for work done in the past for lower levels of the atmosphere, as early as 1894, when the air of New York was sampled (Dyar, 1894). It limits the findings to only those microorganisms which are viable and can grow in the media used.

Impaction has also been used since early investigations (Meier and Lindbergh, 1935; Solomon et al., 1983). In this method, material is collected by collision of aerosols onto Petri dishes or other surfaces, which may be coated with sticky material (e.g. glycerol). For example, the Life's Atmospheric Microbial Boundary (LAMB) balloon payload collected $\sim 100$ cells per glycerol-coated rod, at $\sim 38 \mathrm{~km}$, in a passive sampling mission (Bryan et al., 2014; Griffin et al., 2018). The NASA Cosmic Dust Group were able to collect viable bacteria and fungi, on an impactor plate, in a housing located on the underside of a Lockheed Martin plane that was flown at $20 \mathrm{~km}$ ASL for 2.5 hours from New Mexico to California, USA (Griffin et al., 2004). The method allows for both culturing, as long as the media is suitable, and DNA analysis.

Filtration has been a more common isolation method performed on air samples and lower atmospheric materials. For example, in a study of 
tropospheric dust from dust storms, volumes of 139.5 and 269.7 liters were vacuumed during specific times (15 and 29 minutes, respectively) through pre-sterilized nylon filters with $0.2 \mu \mathrm{m}$ pore size, and a portion of each filter was placed on agar plates for culturing. Using $0.02 \mu \mathrm{m}$ pore size filters, air was also vacuumed for 10 to 15 minutes at a rate of 14.65 to $29.98 \mathrm{~L} /$ minute, for direct counting of average numbers of microbe-like particles using SYBR Gold staining (Griffin et al., 2001). Some problems with this method include possible damage of cellular material during the vacuum stage, and loss of cell viability from impaction with filter materials or media that does not support growth. This method is, at present, hard to perform at the stratospheric altitudes, though collected stratospheric material can be processed over filters. The method allows for both culturing as well as DNA analysis. Radosevich and colleagues (2002) collected air in Utah for which they developed an apparatus based on membrane filtration. From the particles collected, and through bacterial genomic DNA analysis, they were able to find a wide variety of species, many belonging to the phylum Proteobacteria. In other studies, sterile quartz and glass fiber filters were used to collect aerosols from the troposphere over the period of one year and identified archaeal DNA from Thaumarchaeota or Euryarchaeota with seasonal variation (Fröhlich-Nowoisky et al., 2014). Fungal spores had already been determined as being a large part of air particulate matter, and it had already been described a rate higher than initially expected, with a species richness of 368 . These studies concluded that airborne diversity was closely linked to soil diversity, and that soil and soil dust might be the primary source of airborne microorganisms (Fröhlich-Nowoisky et al., 2009; Fröhlich-Nowoisky, 2014).

Cryosampling has also been used in the modern era with cooling of samples during the collection process. This process is expected to increase cell viability and facilitate both culturing and DNA extraction. In one study, sampling of air above Hyderabad, India, employed a cryosampler made of a 16-probe stainless steel manifold with remotecontrolled motorized valves (Wainwright et al., 2003). The payload had a 2meter-long intake tube which was tethered by a rope, both previously sterilized, behind the balloon gondola, in order to avoid the collection of any materials from the balloon surface. Throughout the ascent trip (up to 41 $\mathrm{km}$ ), in order to create a cryopump effect, sequence probes were immersed in liquid neon allowing surrounding air to be collected when the valves were opened. Once all the collections were made, the cryosampler manifold was parachuted back to the ground. Collection of 38.4 and 18.5 liters of air at normal temperature and pressure, was accomplished at 30-39 and 40-41 $\mathrm{km}$ elevations, respectively. The aerosols were aseptically extracted by sequentially filtering the air through 0.45 and $0.22 \mu \mathrm{m}$ micropore cellulose nitrate filters, and then injecting the probes with sterile phosphate buffer solution and agitating in order to release particles adhered to the walls. The subsequent liquid was then sequentially filtered through $0.7 \mu \mathrm{m}$ glass, 0.45 $\mu \mathrm{m}$ and $0.2 \mu \mathrm{m}$ cellulose acetate filters before analysis. Several different 
shaped bacteria were found to be present and one fungal species was isolated (Wainwright et al., 2003).

Another recent method, impingement, involves air collection by suction and then impinged/forced into liquid solutions such as water, buffer or oils. This method allows for the retrieval of the collection media for both microbial culturing (of selected microbes) as well as DNA extraction and subsequent analysis. However, this method is selective for only the cells that can survive in the collection medium. Many studies of the troposphere have used this method since the collection step allows for rapid sampling of large volumes and potential collection of both viable and nonviable material. Though more expensive than membrane filtration, high-flow rate impingers have the advantage of speed. When comparing different air sampling methods, impingers were considered as not appropriate or efficient for the cultivation of certain microorganisms (Cooper et al., 2019). Nevertheless, a study of atmospheric dust collection showed that impingers allow for microbial recovery rates $20 x$ higher than membrane filtration (Griffin et al., 2011). In order to verify the absence of contaminations, impingers - like other air sampling equipment - can initially be analyzed in a sterile test chamber (Cooper et al., 2019).

The more complex cyclonic methods are designed to separate airborne dust into fractions. Air is drawn into a cylindrical chamber by rotation of the air flow, without the use of filters. As a result, aerosols of given sizes move toward the walls by centrifugal force, where they can be rapidly collected (Huard et al., 2010). The force of the collection process may result in some cellular damage and the composition of the walls may further impact microbial survival. This collection method is therefore more suited for DNA sequence analysis of samples than culturing. Furthermore, different designs will have different efficiency values (e.g.: Saunders et al., 2003; Chen et al., 2012).

Sterilization and aseptic techniques are obviously key to any microbiological work, as well as in the field of high-throughput sequencing (Spring et al., 2018). Many methods have been used to clean and sterilize collection vessels and materials, such as use of alcohol wipes, UV-, and ionizing-radiation. For example, in a cryosampling mission to the stratosphere, probes were flushed with acetone and heat sterilized to temperatures of $180{ }^{\circ} \mathrm{C}$ for several hours (Wainwright et al., 2003). More recently, enhanced techniques including the use of sodium hypochlorite for sterilization of refined sampling devises and other culturing and nonculturing methods have also been described (Bryan et al., 2014; 2019).

Some studies of the troposphere have involved using multiple approaches, e.g. both impingement and membrane-filter methods to collect material. For example, Jang et al. (2018) utilized such an approach before and after rainfalls in South Korea, albeit at the low altitude of just $16 \mathrm{~m}$. Combination 
approaches may have the advantage of being more effective than using only a single method to gain broader insight. Nevertheless, collection and culturing of samples from high altitudes remain challenging and further studies are needed to establish standard protocols in high altitude microbiology.

Culturing has been used to identify microbes collected from the stratosphere. Some additional work has been done in comparing phenotypic traits of microbes collected from or exposed to the stratosphere (Table 1). For example, in the early 1930s, several microorganisms were sent up to the stratosphere, on the Explorer II balloon, in order to test the effect of drying, extreme cold, ozone, strong light rays, and low air pressure in the stratosphere on them. These microorganisms were isolated at various times, from the stratosphere (Brachysporium sp., Hysterium sp., Rhizopus sp. from $1.2 \mathrm{~km}$; Diplodia sp., from $1.3 \mathrm{~km}$; and, Aspergillus niger, and Cladosporium sp., from $\sim 3 \mathrm{~km}$ ), as well as from diseased sorghum plants (Helminthosporium sativum). When they returned to Earth, after a flight that lasted ca. 8 hours (Kennedy, 2018), most were able to grow to varying degrees, but one, Hysterium sp., did not (Meier, 1936). This early study illustrated differential effects of the stratosphere on different organisms.

As mentioned before, the equipment used for collection of aerosols may select for and against certain organisms as will culture media and cultivation conditions. Once samples have been collected, they can be inoculated into various media, which so far have mainly been restricted to common bacteriological growth conditions, rather than a wide range needed for culturing diverse microbes, especially those with specific or unusual requirements, such as anaerobic conditions or high salinity. For example, cryosampling of the stratosphere above Hyderabad (India), resulted in the isolation of four new species from the genus Bacillus: $B$. aerius sp. nov., $B$. aerophilus sp. nov., $B$. stratosphericus sp. nov., and $B$. altitudinis sp. nov. (Shivaji et al., 2006). In many studies, such as this one, the selection of microbes cultivated was dependent on the method of collection (cryotubes were flushed with buffer that was then spread on culture media) in this case and the medium used (e.g. Luria-Bertani agar or Nutrient agar), and effectively allowed for the recovery and cultivation only of specific microbes.

A common method for analysis of recovered samples is the use of light, phase, electron and epifluorescence microscopy. In addition to SYBR gold, another analysis used to determine cell viability of material collected, involves using $0.45 \mu \mathrm{m}$ micro-pore filters, treated with either a fluorescent cationic carbocyanine or an anionic oxonol dye, both membrane potentialsensitive (or voltage sensitive) probes (Harris et al., 2002). While determining the viability of cells using dyes may sometimes lead to ambiguous results, generally cationic dyes will penetrate the cell 
membranes of viable, but not of dead cells, while anionic dyes will penetrate the membranes of only non-viable cells (Johnson et al., 2013). Viable cells can usually be visualized using epifluorescence microscopy. Harris and colleagues (2002), discovered clumps of cocci-shaped submicron-sized particles on filters recovered from an earlier stratospheric probe. They were identified as prokaryotic microorganisms, using both scanning electron and epifluorescence microscopy. The epifluorescence microscopy used a membrane potential-sensitive dye (carbocyanine), and fluorescence was suggestive of the presence of viable cells (Wainwright et al., 2003; DasSarma and DasSarma, 2018).

Sequencing analyses of the 16S rRNA gene have been largely used in microbial identification. These allow to simultaneously estimate gene abundances and diversity between samples (Smets et al., 2016). In isolates from the stratosphere, Bacillus luciferensis, collected at $10 \mathrm{~km}$ ASL, was $99 \%$ similar to a volcanic soil $B$. luciferensis isolate, suggesting that the source of the stratospheric isolate might have been from volcanic eruption (Griffin, 2004; Griffin et al., 2018). In another large-scale study of aerosols from $20 \mathrm{~km} \mathrm{ASL}$, in which samples were collected on an impactor Petri dish, four fungal isolates were observed, all of which belonged to the genus Penicillium (Soffen, 1965). In another study, a cryosampler elevated up to $41 \mathrm{~km} \mathrm{ASL}$ was used to collect air samples, and viable, but initially non-cultivable, microbes were found. In subsequent work, two Grampositive bacteria, Bacillus simplex and Staphylococcus pasteuri, and one fungus, Engyodontium album, were cultured and identified by: 16S rRNA sequencing - for bacteria, and morphological traits - for fungi (Wainwright et al., 2003). Griffin (2008), used a sterile impacter device with a layer of glycerol to collect air, from $20 \mathrm{~km} \mathrm{ASL}$, during a flight of 3.6 hours. Several bacteria were isolated after a long incubation period of 7 weeks. And, interestingly, most of the isolated Micrococcaceae and several of the Microbacteriaceae strains were similar to strains previously identified in volcanic soils.

Recently, atmospheric projects have included metagenomic analysis on bioaerosols, but they have been restricted to the troposphere. Metagenomic analysis may not strictly prove the existence of living organisms, since isolated DNA may be associated with dormant or nonviable cell types. However, it is consistent with their presence in the environment and results in a catalog of operational taxonomic units (OTUs) found in a particular sampling of the atmosphere. Moreover, metagenomic analysis can be used on material from nearly all methods of collection and provides considerable depth of data for analysis. For example, filtration may allow for DNA extraction directly from the filter without the need for isolation or culturing. However, those that require growth of microbes, such as the plate-drop method, only provide the opportunity for genomic analysis of cultivatable isolates, but not whole community analysis. 


\section{Effect of stratospheric stressors on microbes}

Several studies have been performed to determine the effects of stratospheric stressors on isolates from the stratosphere as well as terrestrial ones. Bacillus spores could be shielded from damaging UV radiation either by neighboring spores, or by microniches in the platforms they were placed on (mainly metal coupons) or dust particles (Khodadad et al., 2017). Resistance to stratospheric conditions was also studied by exposing two $B$. subtilis strains, one isolated from $20 \mathrm{~km}$ ASL over the Pacific Ocean, and the other from a desert basal outcrop in Arizona (USA). For these two strains, no differences in survival were observed after exposure (Smith et al., 2011). Monolayers of B. pumillus spores (from a spacecraft clean room) were tested for the effects of UV exposure in the stratosphere. The exposure occurred sequentially from 2 to 8 hours, at $\sim 31$ $\mathrm{km}$ ASL, with half the spores exposed to sunlight and the other half shielded from it. Spores with increasing sunlight exposure were more affected, presenting an increase of inactivation directly related to the exposure time. After 8 hours of exposure with direct sunlight, viability decreased more than $99.9 \%$, suggesting that UV was the determining factor. Multi-layers of spores resulted in greater survival, due to shielding, and this finding was later confirmed in the laboratory (Khodadad et al., 2017).

Other research has involved exposing desiccated or lyophilized strains, including several potential pathogens to the stratosphere on balloons. Though many survived, changes in protein expression and metabolic pathways were observed (Chudobova et al., 2015). In a study on the impact of sending microbes in liquid media into the stratosphere, two halophilic archaea, the mesophilic Halobacterium sp. NRC-1 and the biofilm-forming psychrotolerant Antarctic Halorubrum lacusprofundi, both survived launches into the stratosphere on weather balloons. Laboratory experiments showed that the mesophile, was more UV resistant than the psychrophile, while the psychrotolerant strain was more resistant to low temperatures (Anderson et al., 2016; DasSarma et al., 2017). Interestingly, in this study, the psychrotolerant strain, $H$. lacusprofundi, was found to have a 10 -fold better survival when compared to the UV tolerant strain NRC-1 overall. Moreover, other investigations have addressed resistance of halophilic archaea to UV-radiation (including the use of both light and dark repair systems) (Crowley et al., 2006; Boubriak et al., 2008), and the high degree of resistance found has been associated to the presence of multiple copies of the genome within each cell, and the high intracellular concentration of halide ions that act as chemical chaperones. The intracellular salts are able to scavenge ROS, protecting the cells against radiation damage (Oren, 2014). Additional studies of genes involved in IR protection, including extensive molecular biological examinations via knockout and overexpression, have shown the importance of ssDNA binding for survival (DeVeaux et al., 2007; Karan et al., 2014). 
A recent study of the effect of multiple stratospheric stressors used two balloon flights, up to $\sim 25-30 \mathrm{~km}$, to expose yeast desiccated onto polytetrafluoroethylene strips and $B$. subtilis spores as a control. One yeast strain, Naganishia (Cryptococcus) friedmannii 16LV2, found in volcanic soils, was shown to grow through freeze-thaw conditions down to $-6.5^{\circ} \mathrm{C}$, and belongs to a clade previously isolated from the troposphere. Another, Exophiala sp. 15LV1, was previously shown to survive UV-B and C radiation. These two strains survived stratospheric exposure better than $B$. subtilis spores, although $\sim 90 \%$ of the viable cells were inactivated. A third yeast strain, Holtermanniella watticus 16LV1, isolated from the high-altitude volcanic area of the Atacama Desert, lost most of its viability due to desiccation. When desiccated, $H$. watticus was further weakened by low pressure and temperature and did not survive the stratospheric UV exposure. Additionally, an environmental simulation chamber was used to evaluate effects of desiccation combined with other stressors. Desiccation plus exposure to stratospheric low pressure and temperature had a greater impact on the yeasts than the spores (Pulschen et al., 2018).

\section{Additional microbial related parameters analyzed in the laboratory Radiation}

UV, desiccation and cold conditions exposure in the stratosphere can result in DNA damage including single- and double-stranded breaks. In order to survive damaging UV exposure, terrestrial microbes have been known to use a variety of DNA repair mechanisms (Cuthbertson and Pearce, 2017). Some of the best-known examples of extreme resistance to UV and IR are species in the genus Deinococcus (originally Micrococcus). These include Deinococcus radiodurans and Deinococcus geothermalis - nonsporulating microbes known for their efficiency in repairing damaged DNA. These can typically survive acute exposures to ionizing radiation $\geq 12,000$ Gy (with $D$. radiodurans having survived up to 20,000 Gy; Krisko and Radman, 2013), compared to $8,000 \mathrm{~Gy}$ of $\mathrm{y}$-radiation survived by some fungi, while $E$. coli is killed by only 200-800 Gy (Harris et al., 2009). Deinococcus species are also resistant to desiccation by maintaining homeostasis using DNA repair mechanisms, ROS detoxification and accumulation of compatible solutes (Ranawat and Rawat, 2017). Recent stratospheric Deinococcus isolates include a radioresistant orange-pigmented, desiccation-tolerant, UV- and Yradiation resistant bacterium Deinococcus aerius TR0125 (from 0.8-5.8 $\mathrm{km}$ ), and Deinococcus aetherius ST0316 (from 10-12 km above Japan). They were found to have similar radiation resistance traits as $D$. radiodurans in laboratory studies (Yang et al., 2008; Yang et al., 2009; Yang et al., 2010; Satoh et al., 2018). D. aerius was found to encode DNA photolyase involved in UV resistance, as well as, radiation/desiccation response system genes including pprl, pprA, recA, ddrA, and ddrO also found in $D$. radiodurans, $D$. grandis, and $D$. geothermalis. (Du and Gebicki, 2004; Daly et al., 2007; Yang et al., 2008; Satoh et al., 2018). Some species form aggregates, e.g. D. aerius and D. aetherius (Kawaguchi et al., 
2013), and $D$. radiodurans is usually found as tetrads (Eltsov and Dubochet, 2005).

Laboratory experiments on UV tolerance, have been largely based on the premise that solar radiation and high vacuum are the main factors affecting the incidence of microorganisms in the stratosphere and mesosphere. Laboratory research on microorganisms isolated from the upper layers of the atmosphere, showed that conidia of Aspergillus niger are highly resistant to UV irradiation. Moreover, the conidia of Penicillium spp., Papulaspora anomala, and Circinella muscae, or vegetative cells of Micrococcus spp. and Mycobacterium spp. are resistant to high vacuum. Their inactivation varied within the range of 2 to $16 \%$, with an exception of Micrococcus sp., which was higher, $\sim 40 \%$ (Lysenko, 1980). In another study, stratospheric Bacillus isolates (B. aerius, $B$. aerophilus, $B$. stratosphericus and $B$. altitudinis) were found to be more UV-B-resistant than terrestrial $B$. licheniformis MTCC 429T and B. pumilus MTCC 1640T based on CFU, when $100 \mu \mathrm{l}$ culture samples were spread onto nutrient agar plates and exposed to a UV-B lamp (15Wx4) with the lids open (Shivaji et al., 2006).

In a different experiment, the impact of UV-C radiation on the nonheterocystous cyanobacterium Microcystis aeruginosa was examined (Sahu and Šimek, 2013; Phukan et al., 2018). Effects were observed on photo-absorbing pigments such as chlorophyll a, carotenoids, phycocyanin, allophycocyanin and phycoerythrin, proteins involved in photosynthesis such as D1 protein and RuBisCO, and enzymes involved in nitrogen metabolism (Phukan et al., 2018). Similar deleterious effects were also observed, after exposure to UV-C of the nitrogen-fixing heterocystous cyanobacterium, Nostoc muscorum Meg1.

Genomes of UV tolerant non-sporulating microbes isolated from the stratosphere often have been found to contain a high percentage of GC. High GC content has been thought to lead to greater tolerance as a result of avoidance of T-T photoproducts (Kennedy et al., 2001; Griffin, 2004) (Table 1).

Another proposed UV shielding strategy is the formation of aggregates of cells, where the outer cells may protect interior cells against radiation. $M$. luteus, for example, forms cell aggregates and is 100 times more resistant to UV than E. coli (Wainwright et al., 2003). Halorubrum lacusprofundi, which is able to survive trips into the stratosphere, is known to form biofilms and flocculent material, which might also provide cellular shielding (Reid et al., 2006; DasSarma et al., 2017).

Extensive studies have resulted in an increasing understanding of how radiotolerance (tolerance to UV radiation) is expressed in extremophiles and polyextremophiles (DeVeaux et al., 2007; Karan et al., 2014). Many of 
these microorganisms have developed strategies to tolerate radiation like the production of extremolytes and extremozymes which have potential uses for biotechnology and therapeutic industry (Gabani and Singh, 2013). Derivative strains of Halobacterium sp. NRC-1, have been shown to have a high tolerance to high energy ionizing radiation, with an $L D_{50}$ greater than $11 \mathrm{kGy}$. These derivatives were found to overexpress a single-strandedbinding protein operon (rfa3, rfa8, ral), suggesting a novel mechanism of DNA protection and repair (DeVeaux et al., 2007; Karan et al., 2014). Additionally, it was shown that conidia of the insect pathogen Metarhizium robertsii accumulate trehalose and mannitol under nutritive stress conditions leading to an increased UV-B tolerance (Ranawat and Rawat, 2017).

\section{Pigmentation}

From the earliest, pigmentation of isolates was noted and thought to be important for survival in the stratosphere. It has long been suggested that microbes use pigments like melanin and carotenoids for UV protection (Imshenetsky et al., 1978; Tong and Lighthart 1997; Singh and Gabani; 2011; Koller et al., 2014). Recent microscopic examination of cloud material showed that $55 \%$ of detected bacterial cells were pigmented, as well as up to $41 \%$ fungal cells (Vaïtilingom et al., 2012).

Microbes isolated from 48-77 km ASL included pigmented conidia: black from Aspergillus niger, green from Penicillium notatum, and grey from Circinella muscae (Imshenetsky et al., 1979). These strains along with vegetative cells of Micrococcus albus, and unpigmented mutants were subjected to UV treatment. The unpigmented mutants were more UV sensitive, with resistance restored by addition of Aspergillus niger black pigments (which had a maximum radiation absorption range of 210-370 $\mathrm{nm}$ ) (Imshenetsky et al., 1979). Further surveys showed that albino conidia of a Metarhizium robertsii mutant was less UV-B tolerant than the wild-type green conidia (Braga et al., 2001a, 2001b; Rangel et al., 2006; Dias et al., 2018). Interestingly, survival of an unpigmented entomopathogenic fungus, Metarhizium acridum, was noted to be similar to that of the pigmented halophilic Cladosporium herbarum fungus isolated from the stratosphere and Chernobyl nuclear reactor (Zhdanova et al., 2000; Butinar et al., 2005; Rangel et al., 2005; Rangel et al., 2006; Rangel et al., 2010; Braga et al., 2015; Della Corte et al., 2014). Therefore, even though conidium pigmentation seems to be related to radiotolerance, it is not the only factor contributing to resistance.

It is also believed that melanin plays the role of a radioprotector, since melanized fungi are able to survive exposure to high doses of $y$-radiation, lethal to most non-melanized fungi (Dadachova et al., 2008). For example, the melanized fungi Cryptococcus neoformans and $C$. antarcticus are resistant to highly energetic and damaging particulate radiation, e.g. deuterons (Pacelli et al., 2017). Melanin may also be used as an energy 
transducer, allowing for utilization of ionizing radiation for metabolic processes, and increasing growth rates, compared to non-melanized fungi when exposed to higher than background radiation (Dadachova et al., 2008; Robertson et al., 2012).

Carotenoids are known to be important for protection from oxidative stress and UV irradiation. Not surprisingly, many isolates from the stratosphere, as well as the ones that survive exposure, contain carotenoid pigments. These include halophilic archaea, which contain novel C50 isoprenoids, such as bacterioruberins (DasSarma et al., 2001). In these extremophilic organisms, a number of genes have been shown to be involved in their synthesis, including a cytochrome P450 (Hescox and Carlberg, 1972, Müller et al., 2018). Studies have also been carried out on the fungus Aschersonia aleyrodis to show that carotenoids including $\beta$-carotene are involved in oxidative stress and UV irradiation protection (van Eijk et al., 1979; Avalos and Limón, 2015; Dias et al., 2018).

\section{Cold temperature}

Microbes have developed multiple strategies to protect themselves from the damaging effects of freezing, such as: biofilm-formation (Reid et al., 2006), accumulation of chaotropic metabolites (e.g. fructose and glycerol), increase of polyol levels (e.g. intracellular trehalose), change of membrane lipids and fluidity, secretion of antifreeze proteins, and use of cold-active enzymes (Robinson, 2001; Feller and Gerday, 2003; Chin et al., 2010; Gerday 2013, Martin and McMinn 2018). Many studies have addressed the molecular adaptations that allow growth and survival at cold temperatures on the Earth's surface, but relatively few have addressed this property in the high atmosphere (Karan et al., 2012; Gerday 2013). One important property, for protein function at low temperatures, is greater flexibility and less negative charge at the surface (Laye et al., 2017). Microbial membranes also need to be more fluid, which can be achieved by changing saturation levels of fatty acid modifications and shortening of fatty acid chain length. Synthesis of antifreeze glycoproteins and peptides leads to freezing point depression of water and may improve survival at extremely cold temperatures (Pikuta et al., 2007).

Growth of microbes in the laboratory at subzero temperatures has been observed. The proteomics of Colwellia psychrerythraea $34 \mathrm{H}(\mathrm{Cp} 34 \mathrm{H})$ at -1 to $-10{ }^{\circ} \mathrm{C}$ revealed several strategies, including osmolyte regulation and polymer secretion. These appear to be necessary for metabolic activity subzero, while differentially expressed proteins include those involved in DNA repair chemotaxis and sensing (with a drop-in motility-related proteins) (Nunn et al., 2014). The haloarchaeon Halobacterium lacusprofundi, isolated from an Antarctic lake, was found to be capable of growth at sub-zero temperatures in high salt brine and also to be more freeze-thaw resistant than mesophilic haloarchaea (Reid et al., 2006; DasSarma et al., 2017). Additional microbes able to withstand the cold, 
include Trichococcus patagoniensis, which was determined to be able to divide at $-5{ }^{\circ} \mathrm{C}$ under both aerobic and anaerobic conditions (Pikuta et al., 2007).

Studies suggest that polyhydroxyalkanoates (PHA) storage granules may also be involved in cold stress, osmotic shock, and radiation protection (Pavez et al., 2009; Tribelli and López, 2011; Obruca et al., 2016; Obruca et al., 2017). Strains producing PHA have been found to be more UV radiation resistant than mutants that do not produce PHA (Slaninova et al., 2018). This was also observed in Azospirillum brasilense when PHA-rich and PHA poor cells were compared (Tal and Okon, 1985). The granules are believed to scatter UV radiation, shielding bound DNA as well as decreasing intracellular ROS levels. This protection was confirmed using genetically modified E. coli (Slaninova et al., 2018).

\section{Osmotic stress}

The dry conditions, present in large sections of the atmosphere, reduce water availability and induce osmotic stress in cells exposed to them. Osmotic stress often requires multiple stress responses. For example, fungi have been shown to respond by altering ion transport, homeostasis, sodium extrusion, and melanin synthesis. They also adjust their internal solute potentials by accumulating solutes such as glycerol, erythritol, mannitol, and trehalose, modifying the plasma membrane, decreasing fatty acid saturation in membranes, and increasing cell wall thickness to limit osmotic losses (Hallsworth and Magan, 1994; Serrano et al., 1999; Almagro et al., 2001; Turk et al., 2004; Dijksterhuis and de Vries, 2006; Kogej et al., 2007; Rangel et al., 2008; Kralj Kuncic et al., 2010; Rangel, 2011). Further adaptation strategies to osmotic stress have been studied in halophiles, and both salt-in and salt-out strategies have been identified (for more, see review in DasSarma and DasSarma, 2015).

\section{Metabolic activity}

Several observations of microbes from the stratosphere show that they are generally dormant, with suppressed metabolic activity, when isolated. This is consistent with the hypothesis that dormancy conditions prevent excessive DNA damage, which mainly occurs in actively dividing cells. As seen on Table 1, the majority of strains isolated from the stratosphere form spores. For example, in a study of microbes isolated from an altitude of 20 $\mathrm{km}$, several spore-forming pigmented fungi and bacteria were found, including Penicillium sp. and several bacilli (Griffin, 2004). Other observations have indicated that cells grow more slowly upon return from the stratosphere. Slowed growth was reported for the orange-pigmented, non-motile, non-spore-forming Deinococcus aerius TR0125, isolated from $10 \mathrm{~km} \mathrm{ASL}$, which was found to grow at a much slower rate than $D$. radiodurans, D. grandis, and D. geothermalis (Satoh et al., 2018). This is consistent with other findings of slower growth observed for a stratospheric Bacillus sp. isolate (Smith et al., 2010). 
Halotolerant fungi, such as melanized Cladosporium sp., have been isolated from the stratosphere and have been shown to accumulate mycosporines as a response to stress (Della Corte et al., 2014). Aspergillus penicilliodes is able to germinate at very low water activity ( 0.585 aw, approximately $58.5 \%$ of relative humidity), which is now considered the lower limit for life. Studies of this fungus should result in a better understanding of life under severe water limiting conditions, such as found in the stratosphere (Stevenson, 2017; Rangel et al., 2018).

\section{Epidemiology}

While most microbiological research has been conducted in the troposphere, it has been established that several pathogens may be viable even after exposure to the stratosphere (Chudobova et al., 2015). Molecular-based studies of airborne microbes in the troposphere have determined that, during African dust events, up to $25 \%$ present in the Caribbean air are species of bacteria or fungi that are known to be plant pathogens and about $10 \%$ were identified as opportunistic human pathogens (Griffin et al., 2001; Kellogg and Griffin, 2006). Potential pathogens isolated from the troposphere include: Puccinia melanocephala and Hemileia vastatrix, which cause sugar cane and coffee rust respectively; Puccinia graminis, a wheat pathogen; Mycospherella musicola, which causes banana leaf spot disease; Bacillus pumilus, which causes bacterial blotch in peaches; Bacillus megaterium, which causes 'wetwood' disease in trees; Aspergillus sydowii, which has been implicated in sea-fan disease; Karenia brevis, which is a causative agent for algal blooms; and, the causative agent of meningococcal meningitis, Neisseria meningitis (Griffin et al., 2001; Griffin et al., 2002). Since both plant and animal (including human) pathogens have been isolated from the troposphere, the atmosphere may indeed be transporting human pathogenic agents (Griffin et al., 2002). However, how many, if any, are present and transported by the stratosphere is yet undetermined. Further studies are needed to establish the potential epidemiology related to the tropospheric and stratospheric transport of pathogens.

\section{Planetary protection}

Studies of the stratosphere are relevant for planetary protection, which is the practice of protecting solar system bodies from contamination by Earth life and protecting Earth from possible life forms that may be returned from other solar system bodies (OSMA, 2019). Understanding microbial survival and adaptation to stratosphere conditions allows for better definition of policies and helps in their development and establishment. For example, the 1958 Committee on Space Research (COSPAR) developed the original guidelines to minimize forward- and backward- contamination and was the basis for the 1967 Outer Space Treaty that provided planetary protection policies. This included quarantining both astronauts and material for the Apollo program (1969-72) (Nicholson et al., 2009). In the 1960s, 
acceptable unmanned spacecraft microbial bioloads were $10^{4}-10^{8} \mathrm{CFU} /$ vehicle. The Viking 1 and 2 lander missions to Mars, in 1976, were sterilized using heat, reducing spore forming CFU to $2 \times 10^{4} /$ lander. These had the search for life as part of their mission, while all other NASA missions have primarily been geology focused (Fairén et al., 2018). Later missions allowed for higher counts, $<3 \times 10^{5} \mathrm{CFU}$ bacterial spores, in order to reduce sterilization costs (Nicholson et al., 2009).

Roughly $85-95 \%$ of microbial isolates from Spacecraft Assembly Facilities (SAFs) and spacecraft are indigenous to humans, and the remaining have been found in soil and dust. Spore-forming Bacillus spp. isolates from SAFs make up $\sim 10 \%$ of total cultured bioloads (Nicholson et al., 2009). When considering how to effectively sterilize outbound materials, we have to consider the destination. For example, Mars has been, and still is naturally "sterilized" against terrestrial microorganisms, with broadspectrum radiation, extreme cold and dryness, and surface soil chemistry containing highly reactive oxidizing agents and low pressure (Nicholson et al., 2009; Freissinet et al., 2015; Khodadad et al., 2017; Fairén et al., 2017; Fairén et al., 2018).

Planetary Protection constraints exploration of Special Regions of Mars, including the potentially aqueous, briny recurrent slope lineae (RSL), in order not to contaminate these potentially habitable environments. On the other hand, long-term plans include human missions, resulting in transport of large numbers of microbes (Fairén et al., 2017; Rummel and Conley, 2017; Fairén et al., 2018). If a Martian mission leads to the discovery of microbial life, how would one know if this is Martian or hitchhikers from Earth? They could be exobiota from the current climate or from when Mars was warmer, or simply contamination from a launch site or a spacecraft clean-room or assembly facility like the highly UV resistant Bacillus nealsonii, or Bacillus odysseyi (Venkateswaran et al., 2003; La Duc et al., 2009). The stratosphere is likely to be extremely valuable as a Mars simulation region due to their physical-chemical similarities and also serving to test the efficacy of our planetary protection measures. Understanding how Earth's microbes survive stratospheric stressors is likely to help us understand how life from our planet could survive Martian conditions.

In addition to the links to the astrobiological exploration of Mars, such insights will also prove helpful in the future study of the icy moons of the outer solar system and extra solar planets. Discussions on the planetary protection of the exooceans of these moons is an on-going dialogue between different space agencies (Rettberg et al., 2019), and preparations for their future exploration are gaining increased traction and visibility (e.g. Antunes et al., 2020; Jebbar et al., 2020; Taubner et al., 2020). 


\section{Climate change}

Burning of fossil fuels since the industrial revolution has resulted in increasing concentrations of greenhouse gases to levels not seen for more than a million years. For example, the most abundant of these, $\mathrm{CO}_{2}$, ranged from $180-280 \mathrm{ppm}$ for most of the past hundreds of thousands of years, but has increased to $>400 \mathrm{ppm}$ in 2016 . Widespread climate change is occurring as a result, including global warming, sea level rise, extreme storms and flooding, and droughts, wildfires, and desertification. Greenhouse gases and particulate matter affect radiative transfer, changing atmospheric temperature, density and albedo patterns and weather. The role of the stratosphere in climate change has resulted primarily from effects on ozone. The level of ozone in the stratosphere affects the temperature and the height of the tropopause, with significant consequences for the weather and temperature at the Earth's surface (Trickl et al., 2019).

Certain greenhouse gases, especially refrigerants like halocarbon gases (hydrofluorocarbons and chlorofluorocarbons), are known to deplete ozone in the stratosphere via photoreaction (World Meteorological Organization, 2014). Ozone depletion and the subsequent cooling of the stratosphere results in a rise in the temperature of the tropopause with potential impacts on climate (Hoskins, 2003). Cumulonimbus clouds may enter the stratosphere as a consequence, bringing moisture to this layer, but at the same time drying the lower troposphere, resulting in less frequent, but longer-lasting thunderstorms and an effective cooling (Ursem, 2016). A difference in humidity at the tip of the boundary layer in the lower stratosphere can result in nucleation on nanostructured colloidal aerosols and formation of droplets and a visible haze effect - especially in the Arctic, where this haze has become almost permanent, with particle lifetime in the stratosphere predicted to be 1-2 years (compared to $<2$ weeks in the lower troposphere) (Ursem, 2016).

Increased stratospheric cloud formation may in turn increase the rates of ozone depletion, resulting in a damaging cycle. Since the ozone layer within the stratosphere acts as a radiation shield, protecting the Earth's surface from UV-C damage, increased solar UV radiation reaching the Earth's surface harms both plants and animals. Damage to plants suppresses the net photosynthetic rate, and lowers transpiration rate of crops, reducing the overall $\mathrm{CO}_{2}$ sink (Lou et al., 2017; Pérez et al., 2017). As a result, efforts have been made over the past few decades to reduce ozone depleting greenhouse gases such as refrigerants, through the Montreal Protocol. While these have been quite successful, challenges to increased usage of hydrofluorocarbons and other ozone-reactive gases continue to be of concern (Bais et al., 2018).

The atmospheric trace gas $\mathrm{N}_{2} \mathrm{O}$ has also been implicated in climate change, by ozone-depletion in the stratosphere, and is mainly produced by 
microbes ( $35 \%$ from oceanic bacteria and archaea) (Barnes and UpstillGoddard, 2018). The 100-year global warming potential of $\mathrm{N}_{2} \mathrm{O}$ is calculated to be $\sim 300$ times stronger than that of $\mathrm{CO}_{2}$, and its emission has been increasing at a rate of $0.25 \%$ per year, with wastewater treatment plants emitting $3.2 \%$ of the total anthropogenic $\mathrm{N}_{2} \mathrm{O}$ emissions globally (Yan et al., 2017). Methane is another destructive greenhouse gas involved in climate change, although its effects result from ground level, rather than higher atmosphere effects. Natural methane production rates are in turn influenced by climate: as temperature rises, so does methane production in a process known as positive climate feedback (Dean et al., 2018).

Other greenhouse gases are water vapor and molecular hydrogen $\left(\mathrm{H}_{2}\right)$ (Meredith et al., 2017). When water vapor enters the lower stratosphere during severe storms, it leads to hygroscopic growth of sulfate aerosols and subsequent ozone loss by up to $17 \%$ (Bais et al., 2018). Carbonyl sulfide is the most abundant sulfur compound in the troposphere and can be transported into the stratosphere where it is converted to sulfate by photolysis or reactions with $\mathrm{O}$ or $\mathrm{OH}$ radicals, resulting in production of sulfate aerosols, which in turn influence the Earth's radiation balance and causes ozone depletion (Ogawa et al., 2017).

There are many natural sources of particulate matter in the stratosphere which decrease heat absorption and result in global cooling, including volcanic eruptions, conical blue jets (from tops of thunderclouds), smoke from large fires, and photophoretic forces. Negatively charged anthropogenic nanoparticles can be transported to the lower stratosphere and accumulate at $18-20 \mathrm{~km}$. These originate from combustion, industry, aircraft, ground transportation, heating with coal and wood and energy production. Proposals for using dust-like substances (like Loess - defined as an eolian sediment, that has been transported and deposited by the

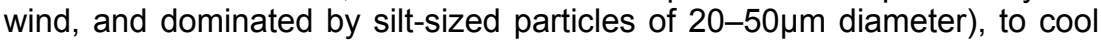
the environment and limit climate change, have been suggested in a process known as geoengineering (Martínez-Garcia et al., 2011; Lamy et al., 2014).

Clearly, complex dynamics are on-going in the stratosphere. The degree to which microorganisms are affected or are affecting these dynamics is largely unknown. Studies are needed to more fully determine their relevance and impact.

\section{Conclusions}

The stratosphere is an extreme environment subject to many simultaneous stressors and is undoubtedly challenging for life. Radiation appears to be the major factor in loss of viability in the stratosphere, but other stressors such as low temperature also limit survival. In addition to being radiationtolerant and cold-tolerant, cells must also be able to tolerate hypobaric conditions to survive the extremely low pressures $(0.1-10 \mathrm{kPa})$ present in 
the stratosphere (Rothchild and Mancinelli, 2001; Fletcher et al., 2014). Stratospheric conditions also lead to rapid desiccation, and only the most xerotolerant microbes are able to cope with such extreme conditions. Due to the sparseness of resources in the stratosphere, it is difficult for any living cells to find the building blocks of life needed to metabolize and reproduce. However, attachment to particulate matter (dust) may provide opportunities to circumvent this limitation.

Whether life can exist for any appreciable length of time in the stratosphere, let alone thrive, is still an open question. What is clear though, is that changes in the stratosphere from human activities are disturbing the troposphere-stratosphere boundary and increasing the exchange of materials between the layers. This reflects the anthropomorphic changes and feedback effects from the troposphere, as well as the surface of the Earth and its oceans, rivers, and lakes. Depletion of the ozone layer represents one of the most destructive potential changes in the stratosphere which may adversely affect animal health, plant life and agriculture.

More detailed investigations involving collection and analysis of stratospheric material will provide better insights into many outstanding questions about the higher atmosphere, including the role of the stratosphere in climate change, long-range dispersal of microorganisms, and implications for planetary protection. In addition, utilizing the stratosphere as a proxy for the surface of Mars will be valuable for astrobiology as we consider the potential for life on the red planet.

\section{Acknowledgements}

Work in the laboratory of PDS and SDS is supported by NASA grant NNH18ZDA001N.

AA and MFS are funded by the Science and Technology Development Fund, Macau SAR.

\section{References}

Aguilera, A., De Diego-Castilla, G., Osuna, S., Bardera, R., Mendi, S. S., Blanco, Y., and González-Toril, E. (2018). Microbial Ecology in the Atmosphere: The Last Extreme Environment. In Extremophilic Microbes and Metabolites-Diversity, Bioprespecting and Biotechnological Applications. IntechOpen.

Almagro, A., Prista, C., Benito, B., Loureiro-Dias, M.C., and Ramos, J. (2001). Cloning and expression of two genes coding for sodium pumps in the salt-tolerant yeast Debaryomyces hansenii. Journal of bacteriology. 183(10), 3251e3255.

Amato, P. (2012). Clouds Provide Atmospheric Oases for Microbes. Microbe. 7(3), 119-123.

Amato, P., Brisebois, E., Draghi, M., Duchaine, C., Fröhlich-Nowoisky, J., Huffman, J.A., Mainelis, G., Robine, E., and Thibaudon, M. (2017). Main Biological Aerosols, Specificities, Abundance, and Diversity. In: Microbiology of Aerosols. John Wiley \& Sons, Inc. pp. 1-21. 
Anderson, I.J., DasSarma, P., Lucas, S., Copeland, A., Lapidus, A., Del Rio, T.G., Tice, H., Dalin, E., Bruce, D.C., Goodwin, L. Pitluck, S. (2016). Complete genome sequence of the Antarctic Halorubrum lacusprofundi type strain ACAM 34. Standards in Genomic Sciences. 11(1), 70.

Antunes, A., Olsson-Francis, K., and McGennity, T. (2020). Exploring deepsea brines as potential terrestrial analogues of oceans in the icy moons of the outer solar system. Current Issues in Molecular Biology (accepted).

Avalos, J. and Limón, C.M. (2015). Biological roles of fungal carotenoids. Current Genetics. 61(3), 309-324.

Bais, A.F., Lucas, R.M., Bornman, J.F., Williamson, C.E., Sulzberger, B., Austin, A.T., Wilson, S.R., Andrady, A.L., Bernhard, G., McKenzie, R.L., Aucamp, P.J., Madronich, S., Neale, R.E., Yazar, S., Young, A.R., de Gruijl, F.R., Norval, M., Takizawa, Y., Barnes, P.W., Robson, T.M., Robinson, S.A., Ballaré, C.L., Flint, S.D., Neale, P.J., Hylander, S., Rose, K.C., Wängberg, S.-Å., Häder, D.-P., Worrest, R.C., Zepp, R.G., Paul, N.D., Cory, R.M., Solomon, K.R., Longstreth, J., Pandey, K.K., Redhwi, H.H., Torikai, A. and Heikkilä, A.M. (2018). Environmental effects of ozone depletion, UV radiation and interactions with climate change: UNEP Environmental Effects Assessment Panel, update 2017. Photochemical \& Photobiological Sciences. 17(2), 121-258.

Barberán, A., Ladau, J., Leff, J.W., Pollard, K.S., Menninger, H.L., Dunn, R.R. and Fierer, N. (2015). Continental-scale distributions of dustassociated bacteria and fungi. Proceedings of the National Academy of Sciences of the United States of America. 112(18), 5756-5761.

Barnes, J. and Upstill-Goddard, R.C. (2018). The denitrification paradox: The role of $\mathrm{O}_{2}$ in sediment $\mathrm{N}_{2} \mathrm{O}$ production. Estuarine, Coastal and Shelf Science. 200, 270-276.

Berera, A. (2017). Space dust collisions as a planetary escape mechanism. Astrobiology. 17(12), 1274-1282.

Boubriak, I., Ng, W.L., DasSarma, P., DasSarma, S., Crowley, D.J., McCready, S.J. (2008). Transcriptional responses to biologically relevant doses of UV-B radiation in the model archaeon, Halobacterium sp. NRC-1. Saline Systems. 4:13.

Braga, G.U.L., Flint, S.D., Miller, C.D., Anderson, A.J. and Roberts, D.W. (2001a). Both solar UVA and UVB radiation impair conidial culturability and delay germination in the entomopathogenic fungus Metarhizium anisopliae. Photochemistry and Photobiology. 74(5), 734-739.

Braga, G.U.L., Flint, S.D., Miller, C.D., Anderson, A.J., and Roberts, D.W. (2001b). Variability in response to UV-B among species and strains of Metarhizium anisopliae isolates from sites at latitudes from $61 \mathrm{~N}$ to $54 \mathrm{~S}$. Journal of Invertebrate Pathology. 78(2), 98-108.

Braga, G.U.L., Rangel, D.E.N., Fernandes, E.K.K., Flint, S.D. and Roberts, D.W. (2015). Molecular and physiological effects of environmental UV radiation on fungal conidia. Current genetics. 61(3), 405-425. 
Bryan, N.C., Stewart, M., Granger, D., Guzik, T.G. and Christner, B.C. (2014). A method for sampling microbial aerosols using high altitude balloons. Journal of Microbiological Methods. 107, 161-168.

Bryan, N.C., Christner, B.C., Guzik, T.G., Granger, D.J. and Stewart, M.F. (2019). Abundance and survival of microbial aerosols in the troposphere and stratosphere. International Society for Microbial Ecology Journal. 13, 2789-2799.

Butinar, L., Sonjak, S., Zalar, P., Plemenitas, A. and Gunde-Cimerman, N. (2005). Melanized halophilic fungi are eukaryotic members of microbial communities in hypersaline waters of solar salterns. Botanica Marina. 48(1), 73-79.

Chen, T.H.B., Feather, G., Keswani, J., and Edgell III, H.D. (2012). U.S. Patent No. 8,205,511. Washington, DC: U.S. Patent and Trademark Office.

Chin, J.P., Megaw, J., Magill, C.L., Nowotarski, K., Williams, J.P., Bhaganna, P., Linton, M., Patterson, M.F., Underwood, G.J.C., Mswaka, A.Y. and Hallsworth, J.E. (2010). Solutes determine the temperature windows for microbial survival and growth. Proceedings of the National Academy of Sciences of the United States of America. 107(17), 7835-7840.

Christian, E.R. (2012). Cosmic Rays. https://helios.gsfc.nasa.gov/ cosmic.html, Accessed on the 12th Jun 2019.

Chudobova, D., Cihalova, K., Jelinkova, P., Zitka, J., Nejdl, L., Guran, R., Klimanek, M., Adam, V. and Kizek, R. (2015). Effects of stratospheric conditions on the viability, metabolism and proteome of prokaryotic cells. Atmosphere. 6(9), 1290-1306.

Cooper, C.W., Aithinne, K.A., Floyd, E.L., Stevenson, B.S. and Johnson, D L. (2019). A comparison of air sampling methods for Clostridium difficile endospore aerosol. Aerobiologia. 35(3), 411-420.

Creamean, J.M., Suski, K.J., Rosenfeld, D., Cazorla, A., DeMott, P.J., Sullivan, R.C., White, A.B., Ralph, F.M., Minnis, P., Comstock, J.M., Tomlinson, J.M. and Prather, K.A. (2013). Dust and Biological Aerosols from the Sahara and Asia Influence Precipitation in the Western U.S. Science. 6127(339), 1572-1578.

Crowley, D.J., Boubriak, I., Berquist, B.R., Clark, M., Richard, E., Sullivan, L., DasSarma, S., McCready, S. (2006). The uvrA, uvrB and uvrC genes are required for repair of ultraviolet light induced DNA photoproducts in Halobacterium sp. NRC-1. Saline Systems. 2:11.

Cunningham, D.D. (1873). Microscopic examinations of air (Calcutta: Superintendent of Government Printing).

Cuthbertson, L. and Pearce, D.A. (2017). Aeromicrobiology. In: Psychrophiles: From Biodiversity to Biotechnology by R. Margesin, ed. (Cham, Switzerland: Springer International Publishing), pp. 41-55.

Dadachova E., Bryan R.A., Howell R.C., Schweitzer A.D., Aisen P., Nosanchuk J.D. and Casadevall A. (2008). The radioprotective properties of fungal melanin are a function of its chemical composition, stable 
radical presence and spatial arrangement. Pigment Cell \& Melanoma Research. 21(2), 192-199.

Daly, M.J., Ouyang, L., Fuchs, P. and Minton, K.W. (1994). In vivo damage and recA-dependent repair of plasmid and chromosomal DNA in the radiation-resistant bacterium Deinococcus radiodurans. Journal of Bacteriology. 176(2), 3508-3517.

Daly, M.J., Gaidamakova, E.K., Matrosova, V.Y., Vasilenko, A., Zhai, M., Leapman, R.D., Lai, B., Ravel, B., Li, S.-M.W., Kemner, K.M. and Fredrickson, J.K. (2007). Protein oxidation implicated as the primary determinant of bacterial radioresistance. PLoS Biol. 5(4), 769-779.

Darwin, C.R. (1846). An account of the fine dust which often falls on vessels in the Atlantic Ocean. Quarterly Journal of the Geological Society of London. 2(1-2), 26-30.

DasSarma S, DasSarma P. (2015). Halophiles and their enzymes: negativity put to good use. Current Opinion in Microbiology. 25:120-126.

DasSarma, S., and DasSarma, P. (2018). Survival of microbes in Earth's stratosphere. Current Opinion in Microbiology. 43, 24-30.

DasSarma, S., Kennedy, S.P., Berquist, B., Ng, W.V., Baliga, N.S., Spudich, J.L., Krebs, M.P., Eisen, J.A., Johnson, C.H. and Hood, L. (2001). Genomic perspective on the photobiology of Halobacterium species NRC-1, a phototrophic, phototactic, and UV-tolerant haloarchaeon. Photosynthesis Research. 70(1), 3-1.

DasSarma, P., Laye, V.J., Harvey, J., Reid, C., Shultz, J., Yarborough, A., Lamb, A., Koske-Phillips, A., Herbst, A., Molina, F., Grah, O., Philips, T. and DasSarma, S. (2017). Survival of halophilic Archaea in Earth's cold stratosphere. International Journal of Astrobiology. 16(4), 321-327.

DasSarma, S. and Schwieterman, E. (2018). Early evolution of purple retinal pigments on Earth and implications for exoplanet biosignatures. International Journal of Astrobiology. 1-10.

Dean, J.F., Middelburg, J.J., Röckmann, T., Aerts, R., Blauw, L.G., Egger, M., Jetten, M.S.M., de Jong, A.E.E., Meisel, O.H., Rasigraf, O., Slomp, C.P., Zandt, M.H. and Dolman, A.J. (2018). Methane Feedbacks to the Global Climate System in a Warmer World. Reviews of Geophysics. 56(1), 207-250.

DeLeon-Rodriguez, N., Lathem, T.L., Rodríguez-R., L., Barazesh, J.M., Anderson, B.E., Beyersdorf, A.J., Ziemba, L.D., Bergin, M., Nenes, A. and Konstantinidis, K.T. (2013). Microbiome of the upper troposphere: Species composition and prevalence, effects of tropical storms, and atmospheric implications. Proceedings of the National Academy of Sciences of the United States of America. 110(7), 2575-2580.

Della Corte, V., Rietmeijer, F.J.M., Rotundi, A. and Ferrari, M. (2014). Introducing a New Stratospheric Dust-Collecting System with Potential Use for Upper Atmospheric Microbiology Investigations. Astrobiology. 14(8), 694-705.

Delort, A.M., Vaïtilingom, M., Amato, P., Sancelme, M., Parazols, M., Mailhot, G., Laj, P. and Deguillaume, L. (2010). A short overview of the 
microbial population in clouds: potential roles in atmospheric chemistry and nucleation processes. Atmospheric Research. 98(2-4), 249-260.

DeVeaux, L.C., Müller, J.A., Smith, J., Petrisko, J., Wells, D.P. and DasSarma, S. (2007). Extremely radiation-resistant mutants of a halophilic archaeon with increased single-stranded DNA-binding protein (RPA) gene expression. Radiation Research. 168(4), 507-514.

Dias, L.P., Araújo, C.A.S., Pupin, B., Ferreira, P.C., Braga, G.U.L. and Rangel, D.E.N. (2018). The Xenon Test Chamber Q-SUN® for testing realistic tolerances of fungi exposed to simulated full spectrum solar radiation. Fungal Biology. 122(6), 592-601.

Dijksterhuis, J. and de Vries, R.P. (2006). Compatible solutes and fungal development. Biochemical Journal. 399(2), e3.

Di Liberto, T. (2018). Dust from the Sahara Desert stretches across the tropical Atlantic Ocean in late June/early July 2018. www.climate.gov/ news-features/event-tracker/dust-sahara-desert-stretches-acrosstropical-atlantic-ocean-late, Accessed on the $12^{\text {th }}$ Jun 2019.

Du, J. and Gebicki, J.M. (2004). Proteins are major initial cell targets of hydroxyl free radicals. The international journal of biochemistry \& cell biology. 36(11), 2334-2343.

Dubos, R. (1986). Louis Pasteur: Free Lance of Science. New York: Da Capo Press.

Dyar, H.G. (1894). XII.- On certain bacteria from the air of New York city. Annals of the New York Academy of Sciences. 8(1), 322-380.

Echigo, A., Hino, M., Fukushima, T., Mizuki, T., Kamekura, M. and Usami, R. (2005). Endospores of halophilic bacteria of the family Bacillaceae isolated from non-saline Japanese soil may be transported by Kosa event (Asian dust storm). Saline Systems. 1(1), 8.

Eltsov, M. and Dubochet, J. (2005). Fine structure of the Deinococcus radiodurans nucleoid revealed by cryoelectron microscopy of vitreous sections. Journal of Bacteriology, 187(23), 8047-8054.

Fairén A.G., Parro V., Schulze-Makuch D. and Whyte L. (2017). Searching for life on Mars before it is too late. Astrobiology. 17(10), 962-970.

Fairén, A.G., Parro, V., Schulze-Makuch, D. and Whyte, L. (2018). Is Searching for Martian Life a Priority for the Mars Community? Astrobiology. 18(2), 101-107.

Feller, G. and Gerday, C. (2003). Psychrophilic enzymes: hot topics in cold adaptation. Nature reviews microbiology. 1(3), 200-208.

Fletcher, C.V., Staskus, K., Wietgrefe, S.W., Rothenberger, M., Reilly, C., Chipman, J.G., Beilman, G.J., Khoruts, A., Thorkelson, A., Schmidt, T.E., Anderson, J., Perkey, K., Stevenson, M., Perelson, A.S., Douek, D.C., Haase, A.T. and Schacker, T.W. (2014). Persistent HIV-1 replication is associated with lower antiretroviral drug concentrations in lymphatic tissues. Proceedings of the National Academy of Sciences of the United States of America. 111(6), 2307-2312.

Freissinet, C.; Glavin, D.P.; Mahaffy, P.R.; Miller, K.E.; Eigenbrode, J.L.; Summons, R.E.; Brunner, A.E., Buch, A., Szopa, C., Archer Jr, P.D., Franz, H.B., Atreya, S.K., Brinckerhoff, W.B., Cabane, M., Coll, P., 
Conrad, P.G., Des Marais, D.J., Dworkin, J.P., Fairén, A.G., François, P., Grotzinger, J.P., Kashyap, S., ten Kate, I.L., Leshin, L.A., Malespin, C.A., Martin, M.G., Martin-Torres, F.J., McAdam, A.C., Ming, D.W., NavarroGonzález, R., Pavlov, A.A., Prats, B.D., Squyres, S.W., Steele, A., Stern, J.C., Sumner, D.Y., Sutter, B., Zorzano, M.-P. and the MSL Science Team. (2015). Organic Molecules in the Sheepbed Mudstone, Gale Crater, Mars. Journal of Geophysical Research: Planets. 120, 495-514.

Fröhlich-Nowoisky J., Pickersgill D.A., Despres V.R. and Pöschl U. (2009). High diversity of fungi in air particulate matter. Proceedings of the National Academy of Sciences of the United States of America. 106(31), 12814-12819.

Fröhlich-Nowoisky, J., Ruzene Nespoli, C., Pickersgrill, D.A., Galand, P.E., Müller-Germann, I., Nunes, T., Gomes Cardoso, J., Almeida, S.A., Pio, C., Andreae, M.O., Conrad, R., Poschl, U. and Desorés, V.R. (2014). Diversity and seasonal dynamics of airborne archaea. Biogeosciences, European Geosciences Union. 11(21), 6067-6079.

Gabani, P. and Singh, O.V. (2013). Radiation-resistant extremophiles and their potential in biotechnology and therapeutics. Applied Microbiology and Biotechnology. 97(3), 993-1004.

Gerday, C. (2013). Psychrophily and catalysis. Biology (Basel). 2(2), 719-741.

Gettelman, A., Hoor, P., Pan, L.L., Randel, W., Hegglin, M.I. and Birner, T. (2011). The extratropical upper troposphere and lower stratosphere. Reviews of Geophysics. 49(3).

Griffin, D.W. (2004). Terrestrial microorganisms at an altitude of 20,000 m in Earth's atmosphere. Aerobiologia. 20(2), 135-140.

Griffin, D.W. (2008). Non-spore forming Eubacteria isolated at an altitude of 20,000 m in Earth's atmosphere: extended incubation periods needed for culture-based assays. Aerobiologia. 24(1), 19-25.

Griffin, D.W., Garrison, V.H., Herman, J.R. and Shinn, E.A. (2001). African desert dust in the Caribbean atmosphere: Microbiology and public health. Aerobiologia. 17(3), 203-213.

Griffin, D.W., Gonzalez-Martin, C., Hoose, C. and Smith, D.J. (2018). Global-Scale Atmospheric Dispersion of Microorganisms. In: Microbiology of Aerosols, First Edition. Delort, A.M. and Amato, P. John Wiley \& Sons, Inc. Hoboken, NJ, USA. pp. 155-194.

Griffin, D.W., Gonzalez, C., Teigell, N., Petrosky, T., Northup, D.E. and Lyles, M. (2011). Observations on the use of membrane filtration and liquid impingement to collect airborne microorganisms in various atmospheric environments. Aerobiologia. 27(1), 25-35.

Griffin, D.W., Kellogg, C.A., Garrison, V.H., Lisle, J.T., Borden, T.C. and Shinn, E.A. (2003). Atmospheric microbiology in the northern Caribbean during African dust events. Aerobiologia. 19(3-4), 143-157.

Griffin, D.W., Kellogg, C.A., Garrison, V.H., and Shinn, E.A. (2002). The Global Transport of Dust: an intercontinental river of dust, microorganisms and toxic chemicals flows through the Earth's atmosphere. American Scientist. 90(3), 228-235. 
Hallsworth, J.E. and Magan, N. (1994). Effects of $\mathrm{KCl}$ concentration on accumulation of acyclic sugar alcohols and trehalose in conidia of three entomopathogenic fungi. Letters in Applied Microbiology. 18(1), 8-11.

Harris, D.R., Pollock, S.V., Wood, E.A., Goiffon, R.J., Klingele, A.J., Cabot, E.L., Schackwitz, W., Martin, J., Eggington, J., Durfee, T.J., Middle, C.M., Norton, J.E., Popelars, M.C., Li, H., Klugman, S.A., Hamilton, L.L., Bane, L.B., Pennacchio, L.A., Albert, T.J., Perna, N.T., Cox, M.M. and Battista, J.R. (2009). Directed evolution of ionizing radiation resistance in Escherichia coli. Journal of Bacteriology. 191(16), 5240-5252.

Harris, M.J., Wickramasinghe, N.C., Lloyd, D., Narlikar, J.V., Rajaratnam, P., Turner, M.P., Al-Mufti, S., Wallis, M.K., Ramadurai, S. and Hoyle, F. (2002). The detection of living cells in stratospheric samples. In: Instruments, Methods, and Missions for Astrobiology IV (Vol. 4495, pp. 192-198). Paper presented at: International Symposium on Optical Science and Technology (San Diego, CA, United States).

Henderson, T.J. and Salem, H. (2016). The Atmosphere: Its Developmental History and Contributions to Microbial Evolution and Habitat. In Aerobiology: The Toxicology of Airborne Pathogens and Toxins. Salem, H., Katz, S.A. (Eds.). Royal Society of Chemistry. pp. 1-41.

Hescox, M.A. and Carlberg, D.M. (1972). Photoreactivation in Halobacterium cutirubrum. Canadian Journal of Microbiology. 18(7), 981-985.

Ho, H.-M., Rao, C.Y., Hsu, H.-H., Chiu, Y.-H., Liu, C.-M. and Chao, H.J. (2005). Characteristics and determinants of ambient fungal spores in Hualien, Taiwan. Atmospheric Environment. 39(32), 5839-5850.

Hoskins, B.J. (2003). Climate change at cruising altitude? Science. 301(5632), 469-470.

Huard, M., Briens, C., Berruti, F. and Gauthier, T. A. (2010). A review of rapid gas-solid separation techniques. International Journal of Chemical Reactor Engineering. 8(1).

Hutchinson, F. (1985). Chemical changes induced in DNA by ionizing radiation. Progress in nucleic acid research and molecular biology. 32, 115-154.

Imlay, J.A. (2006). Iron-sulphur clusters and the problem with oxygen. Molecular Microbiology. 59(4), 1073-1082.

Imshenetsky, A.A., Lysenko, S.V., Kasakov, G.A. and Ramkova, N.V. (1977). Resistance of Stratospheric and Mesospheric Micro-organisms to Extreme Factors. Life sciences and space research. 15, 37-39. Paper presented at: COSPAR Life Sciences and Space Research (Philadelphia, Pennsylvania, USA: Pergamon Press, A. Wheaton \& Co., Exeter).

Imshenetsky, A.A., Lysenko, S.V. and Kazakov, G.A. (1978). Upper Boundary of the Biosphere. Applied and environmental microbiology. 35(1), 1-5.

Imshenetsky, A.A., Lysenko, S.V., Kazakov, G.A. and Ramkova, N.V. (1976). On Micro-organisms of the Stratosphere. Life sciences and space research. 14, 359-362. 
Imshenetsky, A.A., Lysenko, S.V. and Lach, S.P. (1979). Microorganisms of the Upper Layer of the Atmosphere and the Protective Role of their Cell Pigments. In: Life sciences and space research, XVII: Proceedings of the Open Meeting of the W. pp. 105-110.

Jang, G.I., Hwang, C.Y. and Cho, B.C. (2018). Effects of heavy rainfall on the composition of airborne bacterial communities. Frontiers of Environmental Science \& Engineering. 12(2), 12.

Jebbar, M., Cavalazzi, B., Hickman-Lewis, K., Taubner, R.-S., Rittmann, S.K.-M.R. and Antunes, A. (2020). Microbial Diversity and Biosignatures. Space Science Reviews (accepted).

Johnson, S., Nguyen, V. and Coder D. (2013). Assessment of Cell Viability. Current Protocols in Cytometry. 64(1), 9.2.1-9.2.26.

Joung, Y.S., Ge, Z. and Buie, C.R. (2017). Bioaerosol generation by raindrops on soil. Nature communications. 8, 14668.

Karan, R., Capes, M.D. and DasSarma, S. (2012). Function and biotechnology of extremophilic enzymes in low water activity. Aquatic Biosystems. 8(1), 4.

Karan, R., DasSarma, P., Balcer-Kubiczek, E., Weng, R.R., Liao, C.-C., Goodlett, D.R., Ng, W.V. and DasSarma, S. (2014). Bioengineering radioresistance by overproduction of RPA, a mammalian-type singlestranded DNA-binding protein, in a halophilic archaeon. Applied Microbiology and Biotechnology. 98(4), 1737-1747.

Kawaguchi, Y., Yang, Y., Kawashiri, N., Shiraishi, K., Takasu, M., Narumi, I., Satoh, K., Hashimoto, H., Nakagawa, K., Tanigawa, Y., and Momoki, Y. H. (2013). The possible interplanetary transfer of microbes: assessing the viability of Deinococcus spp. under the ISS environmental conditions for performing exposure experiments of microbes in the Tanpopo mission. Origins of Life and Evolution of Biospheres. 43(4-5), 411-428.

Kellogg, C.A. and Griffin, D.W. (2006). Aerobiology and the global transport of desert dust. Trends in Ecology and Evolution. 21(11), 638-644.

Kennedy, S.P., Ng, W.V., Salzberg, S.L., Hood, L. and DasSarma, S. (2001). Understanding the Adaptation of Halobacterium Species NRC-1 to Its Extreme Environment through Computational Analysis of Its Genome Sequence. Genome Research. 11(10), 1641-1650.

Kennedy, G.P. (2018). The two Explorer stratosphere balloon flights. Generated on the $25^{\text {th }}$ Feb. Accessed on the $10^{\text {th }}$ August 2019, http:// stratocat.com.ar/artics/explorer-e.htm

Khodadad, C.L., Wong, G.M., James, L.M., Thakrar, P.J., Lane, M.A., Catechis, J.A. and Smith, D.J. (2017). Stratosphere conditions inactivate bacterial endospores from a Mars spacecraft assembly facility. Astrobiology. 17(4), 337-350.

Klein, A. M., Bohannan, B. J., Jaffe, D. A., Levin, D. A., \& Green, J. L. (2016). Molecular evidence for metabolically active bacteria in the atmosphere. Frontiers in Microbiology. 7, 772.

Kogej, T., Stein, M., Volkmann, M., Gorbushina, A.A., Galinski, E.A. and Gunde-Cimerman, N. (2007). Osmotic adaptation of the halophilic fungus 
Hortaea werneckii: role of osmolytes and melanization. Microbiology. 153(12), 4261-4273.

Koller, M., Muhr, A. and Braunegg, G. (2014). Microalgae as versatile cellular factories for valued products. Algal Research. 6, 52-63.

Kralj Kuncic, M., Kogej, T., Drobne, D. and Gunde-Cimerman, N. (2010). Morphological response of the halophilic fungal genus Wallemia to high salinity. Applied and Environmental Microbiology. 76(1), 329-337.

Krisko, A., and Radman, M. (2013). Biology of extreme radiation resistance: the way of Deinococcus radiodurans. Cold Spring Harbor perspectives in biology. 5(7), a012765.

Kulmala, M., Vehkamäki, H., Petäjä, T., Dal Maso, M., Lauri, A., Kerminen, V.M., Birmili, W. and McMurry, P.H. (2004). Formation and growth rates of ultrafine atmospheric particles: a review of observations. Journal of Aerosol Science. 35(2), 143-176.

La Duc, M.T., Osman, S., Vaishampayan, P., Piceno, Y., Andersen, G., Spry, J.A. and Venkateswaran, K. (2009). Comprehensive Census of Bacteria in Clean Rooms by Using DNA Microarray and Cloning Methods. Applied and Environmental Microbiology. 75(20), 6559-6567.

Lamy, F., Gersonde, R., Winckler, G., Esper, O., Jaeschke, A., Kuhn, G., Ullermann, J., Martinez-Garcia, A.5, Lambert, F. and Kilian, R. (2014). Increased Dust Deposition in the Pacific Southern Ocean During Glacial Periods. Science. 343(6169), 403-407.

Laye, V.J., Karan, R., Kim, J.-M., Pecher, W.T., DasSarma, P. and DasSarma, S. (2017). Key amino acid residues conferring enhanced enzyme activity at cold temperatures in an Antarctic polyextremophilic $\beta$ galactosidase. Proceedings of the National Academy of Sciences of the United States of America. 114(47), 12530-12535.

Leary, K. (2018). In 2017, the US Led the World in Successful Orbital Launches. https://futurism.com/2017-us-led-world-successful-orbitallaunches

Lederberg, J. (1960). Exobiology: Approaches to Life beyond the Earth. Science. 132(3424), 393-400.

Lou, Y., Gu, X. and Zhou, W. (2017). Effect of Elevated UV-B Radiation on Microbial Biomass and Soil Respiration in Different Barley Cultivars Under Field Conditions. Water, Air, and Soil Pollution. 228(3), 96.

Lutgens, F.K. and Tarbuck, E.J. (1995). The Atmosphere: an introduction to meteorology. Prentice Hall, $6^{\text {th }}$ edition. pp. 14-17.

Lysenko, S.V. (1980). Resistance of microorganisms of upper layers of the atmosphere to ultraviolet radiation and a high vacuum. Mikrobiologiia. 49(1), 175-177.

Maki, T., Ishikawa, A., Kobayashi, F., Kakikawa, M., Aoki, K., Mastunaga, T., Hasegawa, H. and Iwasaka, Y. (2011). Effects of Asian dust (KOSA) deposition event on bacterial and microalgal communities in the Pacific Ocean. Asian Journal of Atmospheric Environment. 5(3), 157-163.

Martin, A. and McMinn, A. (2018). Sea ice, extremophiles and life on extraterrestrial ocean worlds. International Journal of Astrobiology. 17(1), 1-6. 
Martínez-Garcia, A., Rosell-Melé, A., Jaccard, S.L., Geibert, W., Sigman, D.M. and Haug, G.H. (2011). Southern Ocean dust-climate coupling over the past four million years. Nature. 476(7360), 312-315.

Meier, F.C. (1936). Paper, US Army Air Corps Stratosphere Flight of 1935 in Balloon Explorer II. National Geographic Society; Washington DC, pp. 152-153.

Meier, F.C. and Lindbergh, C.A. (1935). Collecting Micro-Organisms from the Arctic Atmosphere: With Field Notes and Material. Scientific Monthly. 40, 5-20.

Meredith, L.K., Commane, R., Keenan, T.F., Klosterman, S.T., Munger, J.W., Templer, P.H., Tang, J., Wofsy, S.C. and Prinn, R.G. (2017). Ecosystem fluxes of hydrogen in a mid-latitude forest driven by soil microorganisms and plants. Global Change Biology. 23(2), 906-919.

Moeller, R. and Horneck, G. (2004). Bacillus Endospores-an ideal exobiological Tool. In 35th COSPAR Scientific Assembly 35. pp. 2596.

Mohanakumar, K. (2008). Structure and composition of the lower and middle atmosphere. Stratosphere Troposphere Interactions: An Introduction. pp. 1-53.

Müller, W.J., Smit, M.S., van Heerden, E. Capes, M.D. and DasSarma, S. (2018). Complex Effects of Cytochrome P450 Monooxygenase on Purple Membrane and Bacterioruberin Production in an Extremely Halophilic Archaeon: Genetic, Phenotypic, and Transcriptomic Analyses. Frontiers in Microbiology. 9, 2563.

Nicholson, W.L., Schuerger, A.C. and Race, M.S. (2009). Migrating microbes and planetary protection. Trends in Microbiology. 17(9), 389-392.

Nunn, B.L., Slattery, K.V., Cameron, K.A., Timmins-Schiffman, E. and Junge, J. (2014). Proteomics of Colwellia psychrerythraea at subzero temperatures - a life with limited movement, flexible membranes and vital DNA repair. Environmental Microbiology. 17(7), 2319-2335.

Obruca, S., Sedlacek, P., Krzyzanek, V., Mravec, F., Hrubanova, K., Samek, O., Kucera, D., Benesova, P. and Marova, I. (2016). Accumulation of Poly(3-hydroxybutyrate) Helps Bacterial Cells to Survive Freezing. PLoS One. 11(6), e0157778.

Obruca, S., Sedlacek, P., Mravec, F., Krzyzanek, V., Nebesarova, J., Samek, O., Kucera, D., Benesova, P., Hrubanova, K., Milerova, M. and Marova, I. (2017). The presence of PHB granules in cytoplasm protects non-halophilic bacterial cells against the harmful impact of hypertonic environments. New Biotechnology. 39, 68-80.

Ogawa, T., Hattori, S., Kamezaki, K., Kato, H., Yoshida, N. and Katayama, Y. (2017). Isotopic Fractionation of Sulfur in Carbonyl Sulfide by Carbonyl Sulfide Hydrolase of Thiobacillus thioparus THI115. Microbes and Environments. ME17130.

Oren, A. (2014). Halophilic archaea on Earth and in space: growth and survival under extreme conditions. Philosophical Transactions of the Royal Society A: Mathematical, Physical and Engineering Sciences. 372(2030), 20140194. 
Orr Jr, C. and Keng, E.Y. (1964). Photophoretic effects in the stratosphere. Journal of the Atmospheric Sciences. 21(5), 475-478.

Office of Safety and Mission Assurance - OSMA. (2019). Planetary Protection. NASA. https://sma.nasa.gov/sma-disciplines/planetaryprotection (last accessed 10th Nov 2019).

Pacelli C., Selbmann L., Moeller R., Zucconi L., Fujimori A. and Onofri, S. (2017). Cryptoendolithic Antarctic Black Fungus Cryomyces antarcticus Irradiated with Accelerated Helium Ions: Survival and Metabolic Activity, DNA and Ultrastructural Damage. Frontiers in Microbiology. 8, 2002.

Pasko, V.P., Stanley, M.A., Mathews, J.D., Inan, U.S. and Wood, T.G. (2002). Electrical discharge from a thundercloud top to the lower ionosphere. Nature. 416(6877), 152-14.

Pasteur, M.L. (1860). Nouvelles experiences relatives aux generations dites spontanees (Paris: Mallet-Bachelier, Imprimeur-Libraire).

Pavez, P, Castillo, J.L., González, C. and Martínez, M. (2009). Poly- $\beta-$ hydroxyalkanoate exert a protective effect against carbon starvation and frozen conditions in Sphingopyxis chilensis. Current Microbiology. 59(6), 636-640.

Pérez, V., Hengst, M., Kurte, L., Dorador, C., Jeffrey, W.H., Wattiez, R., Molina, V. and Matallana-Surget, S. (2017). Bacterial survival under extreme UV radiation: a comparative proteomics study of Rhodobacter $\mathrm{sp}$., isolated from high altitude wetlands in Chile. Frontiers in Microbiology. 8, 1173.

Pérez-Díaz, J.L., Ivanov, O., Peshev, Z., Álvarez-Valenzuela, M.A., Valiente-Blanco, I., Evgenieva, T., Dreischuh, T., Gueorguiev, O., Todorov, P.V. and Vaseashta, A. (2017). Fogs: Physical Basis, Characteristic Properties, and Impacts on the Environment and Human Health. Water. 9(10), 807.

Phukan, T., Rai, A.N. and Syiem, M.B. (2018). Dose dependent variance in UV-C radiation induced effects on carbon and nitrogen metabolism in the cyanobacterium Nostoc muscorum Meg1. Ecotoxicology and Environmental Safety. 155, 171-179.

Pikuta, E.V., Hoover, R.B. and Tang, J. (2007). Microbial Extremophiles at the Limits of Life. Critical Reviews in Microbiology. 33, 183-209.

Proctor, B. E. (1934). The microbiology of the upper air. I. In Proceedings of the American Academy of Arts and Sciences (Vol. 69, No. 8, pp. 315-340). American Academy of Arts \& Sciences.

Pulschen, A.A., de Araujo, G.G., de Carvalho, A.C.S.R., Cerini, M.F., de Mendonça Fonseca,L., Galante, D. and Rodrigues, F. (2018). Survival of extremophilic yeasts to the stratospheric environment on balloon flights and laboratory simulations. Applied and Environmental Microbiology. 84(23), e01942-18.

Radosevich, J.L., Wilson, W.J., Shinn, J.H., DeSantis, T.Z. and Andersen, G.L. (2002). Development of a high-volume aerosol collection system for the identification of air-borne micro-organisms. Letters in Applied Microbiology. 34, 162-167. 
Ranawat, P. and Rawat, S. (2017). Radiation resistance in thermophiles: mechanisms and applications. World Journal of Microbiology \& Biotechnology. 33, 111-113.

Rangel, D.E.N. (2011). Stress induced cross-protection against environmental challenges on prokaryotic and eukaryotic microbes. World Journal of Microbiology \& Biotechnology. 27(6), 1281-1296.

Rangel, D.E.N., Alston, D.G. and Roberts, D.W. (2008). Effects of physical and nutritional stress conditions during mycelial growth on conidial germination speed, adhesion to host cuticle, and virulence of Metarhizium anisopliae, an entomopathogenic fungus. Mycological Research. 112 (11), 1355-1361.

Rangel, D.E.N., Braga, G.U.L., Anderson, A.J. and Roberts, D.W. (2005). Influence of growth environment on tolerance to UV-B radiation, germination speed, and morphology of Metarhizium anisopliae var. acridum conidia. Journal of Invertebrate Pathology. 90(1), 55-58.

Rangel, D.E.N., Butler, M.J., Torabinejad, J., Anderson, A.J., Braga, G.U.L., Day, A.W. and Roberts, D.W. (2006). Mutants and isolates of Metarhizium anisopliae are diverse in their relationships between conidial pigmentation and stress tolerance. Journal of Invertebrate Pathology. 93(3), 170-182.

Rangel, D.E.N., Fernandes, E.K.K., Dettenmaier, S.J. and Roberts, D.W. (2010). Thermotolerance of germlings and mycelium of the insectpathogenic fungus Metarhizium spp. and mycelial recovery after heat stress. Journal of Basic Microbiology. 50(4), 344-350.

Rangel, D.E.N., Finlay, R.D., Hallsworth, J.E., Dadachova, E. and Gadd, G.M. (2018). Fungal strategies for dealing with environment- and agriculture-induced stresses. Fungal Biology. 122(6), 602-612.

Rastelli, E., Corinaldesi, C., Dell'Anno, A., Lo Martire, M., Greco, S., Facchini, M.C., Rinaldi, M., O'Dowd, C., Ceburnis, D. and Danovaro, R. (2017). Transfer of labile organic matter and microbes from the ocean surface to the marine aerosol: an experimental approach. Sci Rep. 7(1), 11475.

Reche, I., D'Orta, G., Mladenov, N., Winget, D.M. and Suttle, C.A. (2018). Deposition rates of viruses and bacteria above the atmospheric boundary layer. The ISME Journal. 12, 1154-1162.

Reid, I., Sparks, W., Lubow, S., McGrath, M., Livio, M., Valenti, J., Sowers, K., Shukla, H., MacAuley, S. and Miller, T. (2006). Terrestrial models for extraterrestrial life: methanogens and halophiles at Martian temperatures. International Journal of Astrobiology. 5, 89-97.

Rettberg, P., Antunes, A., Brucato, J., Cabezas, P., Collins, G., Haddaji, A., Kminek, G., Leuko, S., McKenna-Lawlor, S., Moissl-Eichinger, C. and Fellous, J.L. (2019). Biological Contamination Prevention for Outer Solar System Moons of Astrobiological Interest: What Do We Need to Know? Astrobiology. 19, 951-974.

Robertson, K.L., Mostaghim, A., Cuomo, C.A., Soto, C.M., Lebedev, N., Bailey, R.F. and Wang, Z. (2012). Adaptation of the Black Yeast 
Wangiella dermatitidis to lonizing Radiation: Molecular and Cellular Mechanisms. PLoS ONE. 7(11), e48674.

Robinson, C.H. (2001). Cold adaptation in Arctic and Antarctic fungi. New Phytologist. 151, 341-353.

Rogers, L.A. and Meier, F.C. (1936). National Geographic Society, Technical Papers. 146-151.

Rohatschek, H. (1984). The Role of Gravitophotophoresis for Stratospheric and Mesospheric Particulates. Journal of Atmospheric Chemistry. 1, 377-389.

Rohatschek, H. (1996). Levitation of Stratospheric and Mesospheric Aerosols by Gravito-Photophoresis. Journal of Aerosol Science. 27(3), 467-475.

Rothschild, L. and Mancinelli, R.L. (2001). Life in extreme environments. Nature (London). 409, 1092-1101.

Rummel, J.D. and Conley, C.A. (2017). Four Fallacies and an Oversight: Searching for Martian Life. Astrobiology. 17, 10.

Sahu, J.K. and Šimek, M. (2013). Effect of UV-C on thylakoid arrangement, pigment content and nitrogenase activity in the cyanobacterium Microchaete sp. Indian Journal of Experimental Biology. 51, 388-392.

Satoh, K., Arai, H., Sanzen, T., Kawaguchi, Y., Hayashi, H., Yokobori, S.-i., Yamagishi, A., Oono, Y. and Narumic, I. (2018). Draft Genome Sequence of the Radioresistant Bacterium Deinococcus aerius TR0125, Isolated from the High Atmosphere above Japan. Genome announcements. 6.

Saunders, D.H., Arato, E.G., and Davies, O.M. (2003). U.S. Patent No. $6,531,066$. Washington, DC: U.S. Patent and Trademark Office.

Shivaji, S., Chaturvedi, P., Suresh, K., Reddy, G.S.N., Dutt, C.B.S., Wainwright, M., Narlikar, J.V. and Bhargava, P.M. (2006). Bacillus aerius sp. nov., Bacillus aerophilus sp. nov., Bacillus stratosphericus sp. nov. and Bacillus altitudinis sp. nov., isolated from cryogenic tubes used for collecting air samples from high altitudes. International Journal of Systematic and Evolutionary Microbiology. 56, 1465-1473.

Serrano, R., Mulet, J.M., Rios, G., Marquez, J.A., de Larrinoa, I.F., Leube, M.P., Mendizabal, I., Pascual-Ahuir, A., Proft, M., Ros, R. and Montesinos, C. (1999). A glimpse of the mechanisms of ion homeostasis during salt stress. Journal of Experimental Botany. 50, 1023-1036.

Singh, O.V. and Gabani, P. (2011). Extremophiles: radiation resistance microbial reserves and therapeutic implications. Journal of Applied Microbiology. 110(4), 851-861.

Slaninova, E., Sedlacek, P., Mravec, F., Mullerova, L., Samek, O., Koller, M., Hesko, O., Kucera, D., Marova, I. and Obruca, S. (2018). Light scattering on PHA granules protects bacterial cells against the harmful effects of UV radiation. Applied Microbiology and Biotechnology. 102(4), 1923-1931.

Smets, W., Leff, J.W., Bradford, M.A., McCulley, R.L., Lebeer, S. and Fierer, N. (2016). A method for simultaneous measurement of soil bacterial abundances and community composition via 16S rRNA gene sequencing. Soil Biology \& Biochemistry. 96, 145-151. 
Smith, D.J., Griffin, D.W. and Schuerger, A.C. (2010). Stratospheric microbiology at $20 \mathrm{~km}$ over the Pacific Ocean. Aerobiologia. 26, 35-46.

Smith, D.J., Griffin, D.W., McPeters, R.D., Ward, P.D. and Schuerger, A.C. (2011). Microbial survival in the stratosphere and implications for global dispersal. Aerobiologia. 27(4), 319-332.

Smith, D.J., Jaffe, D.A., Birmele, M.N., Griffin, D.W., Schuerger, A.C., Hee, J. and Roberts, M.S. (2012). Free Tropospheric Transport of Microorganisms from Asia to North America. Environmental Microbiology. 64, 973-985.

Smith, D.J. and Sowa, M.B. (2017). Ballooning for Biologists: Mission Essentials for Flying Life Science Experiments to Near Space on NASA Large Scientific Balloons. Gravitational and Space Research. 5, 52-73.

Smith, D.J., Timonen, H.J., Jaffe, D.A., Griffin, D.W., Birmele, M.N., Perry, K.D., Ward, P.D. and Roberts, M.S. (2013). Intercontinental Dispersal of Bacteria and Archaea by Transpacific Winds. Applied and Environmental Microbiology. 79, 1134-1139.

Spring, A.M., Docherty, K.M., Domingue, K.D., Kerber, T.V., Mooney, M.M., AND Lemmer, K.M. (2018). A Method for Collecting Atmospheric Microbial Samples From Set Altitudes for Use With Next-Generation Sequencing Techniques to Characterize Communities. Air, Soil and Water Research. 11, 1178622118788871.

Soffen, G.A. (1965). Atmospheric Collection at 130,000 Feet. Proceedings of the Atmospheric Biology Conference, 1965, Minneapolis, Minnesota, USA 213-219.

Solomon, P.A., Moyers, J.L. and Fletcher, R.A. (1983). High volume dichotomous virtual impactor for the fractionation and collection of particles according to aerodynamic size. Aerosol Science and Technology. 2, 455-464.

Stadtman, E.R. and Levine, R.L. (2003). Free radical-mediated oxidation of free amino acids and amino acid residues in proteins. Amino Acids. 25, 207-218.

Stevenson, D.S. (2017). Ultimately, Can Life Survive? In: The Nature of Life and Its Potential to Survive, Astronomer's Universe. Springer International Publishing. 341-384.

Tal, S. and Okon, Y. (1985). Production of the reserve material poly- $\beta$ hydroxybutyrate and its function in Azospirillum brasilense $\mathrm{Cd}$. Canadian journal of microbiology. 31(7), 608-613.

Taubner, R.-S., Olsson-Francis, K., Vance, S., Ramkissoon, N.R., Postberg, F., de Vera, J.-P., Antunes, A., Casas, E.C., Sekine, Y., Noack, L., Barge, L., Goodman, J., Jebbar, M., Journaux, B., Karatekin, Ö., Klenner, F., Rabbow, E., Rettberg, P., Rückriemen-Bez, T., Saur, J., Shibuya, T., and Sonderlund, K. (2020). Experimental and Simulation Efforts in the Astrobiological Exploration of Exooceans. Space Science Reviews (accepted).

Tong, Y. and Lighthart, B. (1997). Solar Radiation Is Shown to Select for Pigmented Bacteria in the Ambient Outdoor Atmosphere. Photochemistry and Photobiology. 65(1), 103-106. 
Tribelli, P.M. and López, N.I. (2011). Poly(3-hydroxybutyrate) influences biofilm formation and motility in the novel Antarctic species Pseudomonas extremaustralis under cold conditions. Extremophiles. 15(5), 541-547.

Trickl, T., Vogelmann, H., Ries, L. and Sprenger, M. (2019). Very high stratospheric influence observed in the free troposphere over the Northern Alps - just a local phenomenon? Atmospheric Chemistry and Physics Discussions. https://doi.org/10.5194/acp-2019-588, in review.

Turk, M., Mejanelle, L., Sentjurc, M., Grimalt, J.O., Gunde-Cimerman, N. and Plemenitas, A. (2004). Salt-induced changes in lipid composition and membrane fluidity of halophilic yeast-like melanized fungi. Extremophiles. 8(1), 53-61.

UNSCEAR "Sources and Effects of lonizing Radiation" page 339 retrieved 2011-6-29 www.unscear.org/docs/reports/2008/09-86753_Report_2008_Annex_B.pdf

Ursem, B. (2016). Climate Shifts and the Role of Nano Structured Particles in the Atmosphere. Atmospheric and Climate Sciences. 6(1), 51-76.

Vaïtilingom, M., Attard, E., Gaiani, N., Sancelme, M., Deguillaume, L., Flossmann, A.I., Amato, P. and Delort, A.-M. (2012). Long-term features of cloud microbiology at the puy de Dôme (France). Atmospheric Environment. 56, 88-100.

Vaïtilingom, M., Deguillaume, L., Vinatier, V., Sancelme, M., Amato, P., Chaumerliac, N. and Delorta, A.-M. (2013). Potential impact of microbial activity on the oxidant capacity and organic carbon budget in clouds. Proceedings Academy of Science USA. 110(2), 559-564.

van Eijk, G.W., Mummery, R.S., Roeymans, H.J. and Valadon, L.R. (1979). A comparative study of carotenoids of Aschersonia aleyroides and Aspergillus giganteus. Antonie Van Leeuwenhoek. 45(3), 417-422.

von Sonntag, C. (1987). The chemical basis of radiation biology. London: Taylor \& Francis.

Vargin, P.N., Volodin, E.M., Karpechko, A.Y. and Pogoreltsev, A.I. (2015). Stratosphere-Troposphere Interactions. Herald of the Russian Academy of Sciences/Vestnik Rossiiskoi Akademii Nauk. 85, 56-63.

Venkateswaran, K., Kempf, M., Chen, F., Satomi, M., Nicholson, W. and Kern, R. (2003). Bacillus nealsonii sp. nov., isolated from a spacecraftassembly facility, whose spores are gamma-radiation resistant. International Journal of Systematic and Evolutionary Microbiology. 53(1), 165-172.

Wainwright, M., Wickramasinghe, N.C., Narlikar, J.V. and Rajaratnam, P. (2003). Microorganisms cultured from stratospheric air samples obtained at $41 \mathrm{~km}$. FEMS Microbiology Letters. 218(1), 161-165.

Wells, W.F. and Fair, G.M. (1935). Viability of B. coli exposed to ultra-violet radiation in air. Science. 82(2125), 280-281.

Whisler, B. (1940). The efficacy of ultra-violet light sources in killing bacteria suspended in air. lowa State College Journal of Science. 14, 215-231.

World Meteorological Organization, Scientific Assessment of Ozone Depletion. (2014). World Meteorological Organization, Global Ozone 
Research and Monitoring Project-Report No. 55, Geneva, Switzerland, 2014. pp. 416

Wilson, L., Sparks, R.S.J., Huang, T.C. and Watkins, N.D. (1978). The control of volcanic column heights by eruption energetics and dynamics. Journal of Geophysical Research: Solid Earth. 83(B4), 1829-1836.

Wu, P.-C., Tsai, J.-C., Li, F.-C., Lung, S.-C. and Su, H.-J. (2004). Increased levels of ambient fungal spores in Taiwan are associated with dust events from China. Atmospheric Environment. 38(29), 4879-4886.

Xu, C., Wei, M., Chen, J., Sui, X., Zhua, C., Li, J., Zheng, L., Sui, G., Li, W., Wang, W., Zhang, Q. and Mellouki, A. (2017). Investigation of diverse bacteria in cloud water at Mt. Tai, China. Science of the Total Environment. 580, 258-265.

Yan, X., Zheng, J., Han, Y., Liu, J. and Sun, J. (2017). Effect of influent C/N ratio on $\mathrm{N}_{2} \mathrm{O}$ emissions from anaerobic/anoxic/oxic biological nitrogen removal processes. Environmental Science and Pollution Research. 24(30), 23714-23724.

Yang, Y., Itahashi, S., Yokobori, S. and Yamagishi, A. (2008). UV-resistant bacteria isolated from upper troposphere and lower stratosphere. Biological Sciences in Space. 22(1), 18-25.

Yang, Y., Itoh, T., Yokobori, S., Shimada, H., Itahashi, S., Satoh, K., Ohba, H., Narumi, I. and Yamagishi, A. (2010). Deinococcus aetherius sp. nov., isolated from the stratosphere. International Journal of Systematic and Evolutionary Microbiology. 60(4), 776-779.

Yang, Y., Itoh, T., Yokobori, S., Itahashi, S., Shimada, H., Satoh, K., Ohba, H., Narumi, I. and Yamagishi, A. (2009). Deinococcus aerius sp. nov., isolated from the high atmosphere. International Journal of Systematic and Evolutionary Microbiology. 59(8), 1862-1866.

Zhdanova, N.N., Zakharchenko, V.A., Vember, V.V. and Nakonechnaya, L.T. (2000). Fungi from Chernobyl: mycobiota of the inner regions of the containment structures of the damaged nuclear reactor. Mycological Research. 104(12), 1421-1426. 